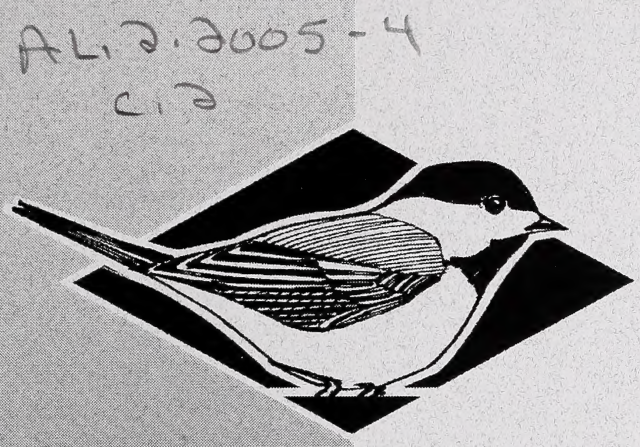

\section{Fish \& Whillie Division}

RESOURCE DATA AND SPECLS AT RISK SECIION

\title{
Status of the Tiny Cryptanthe (Cryptantha minima) in Alberta
}

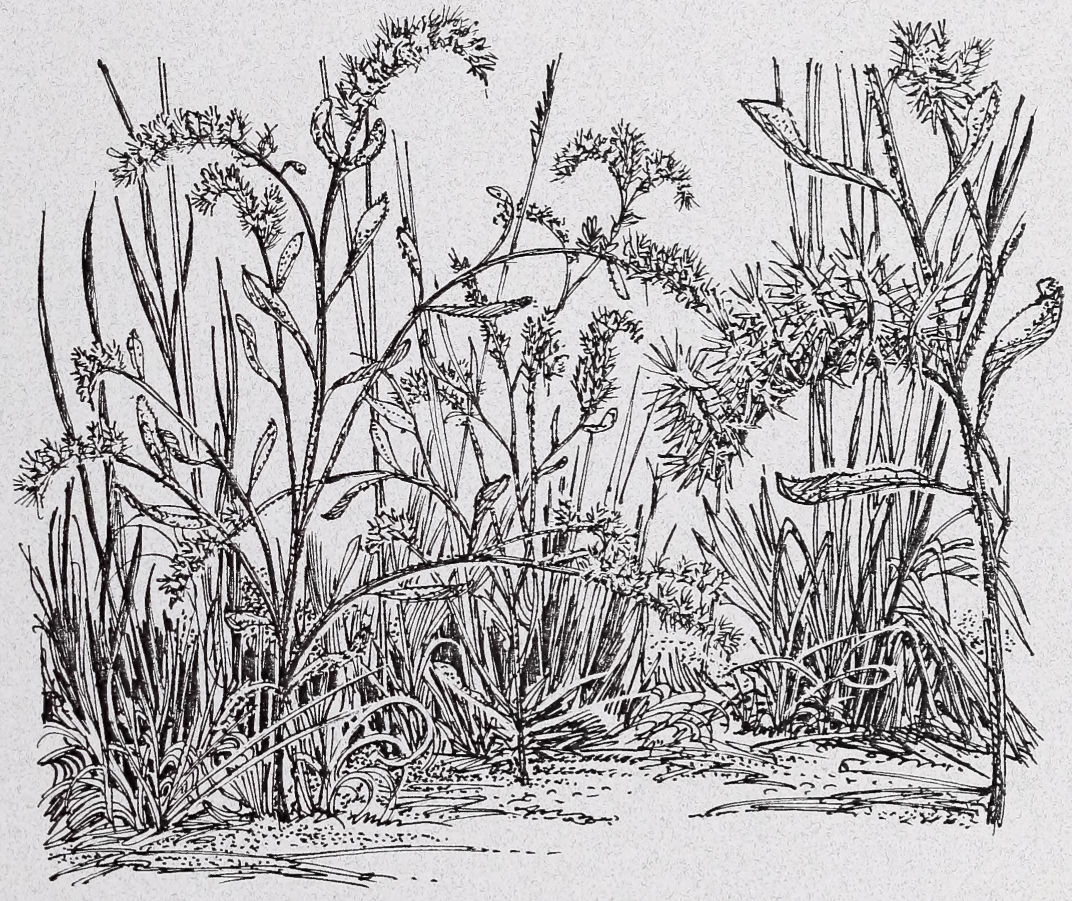

Alberta Wildlife Status Report No. 54

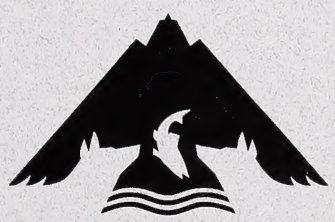

Alberta Conservation Association 



\section{Status of the Tiny Cryptanthe (Cryptantha minima) in Alberta}

Prepared for:

Alberta Sustainable Resource Development (SRD)

Alberta Conservation Association (ACA)

Prepared by:

Cheryl Bradley

This report has been reviewed, revised, and edited prior to publication.

It is an SRD/ACA working document that will be revised and updated periodically.

Alberta Wildlife Status Report No. 54

September 2004

Published By:

410

SUSTAINABLE RESOURCE DEVELOPMENT

Fish \& Wildlife

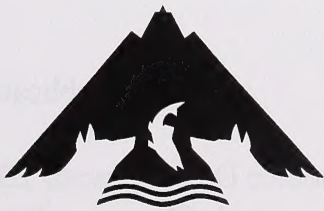

Alberta Conservation Association 
Publication No. T/064

ISBN: 0-7785-3632-7 (Printed Edition)

ISBN: 0-7785-3633-5 (On-line Edition)

ISSN: 1206-4912 (Printed Edition)

ISSN: 1499-4682 (On-line Edition)

Series Editors: Sue Peters, Nyree Sharp and Robin Gutsell

Illustrations: Brian Huffman

Maps: Jane Bailey

For copies of this report,visit our web site at :

http://www3.gov.ab.ca/srd/fw/riskspecies/

and click on "Detailed Status"

$O R$

Contact:

Information Centre - Publications

Alberta Environment/Alberta Sustainable Resource Development

Fish and Wildlife Division

Main Floor, Great West Life Building

9920 - 108 Street

Edmonton, Alberta, Canada T5K 2M4

Telephone: (780) 422-2079

This publication may be cited as:

Alberta Sustainable Resource Development. 2004. Status of the tiny cryptanthe (Cryptantha minima) in Alberta. Alberta Sustainable Resource Development, Fish and Wildlife Division, and Alberta Conservation Association, Wildlife Status Report No. 54, Edmonton, AB. 39 pp. 


\section{PREFACE}

Every five years, the Fish and Wildlife Division of Alberta Sustainable Resource Development reviews the general status of wildlife species in Alberta. These overviews, which have been conducted in 1991 (The Status of Alberta Wildlife), 1996 (The Status of Alberta Wildlife) and 2000 (The General Status of Alberta Wild Species 2000), assign individual species "ranks" that reflect the perceived level of risk to populations that occur in the province. Such designations are determined from extensive consultations with professional and amateur biologists, and from a variety of readily available sources of population data. A key objective of these reviews is to identify species that may be considered for more detailed status determinations.

The Alberta Wildlife Status Report Series is an extension of the general status exercise, and provides comprehensive current summaries of the biological status of selected wildlife species in Alberta. Priority is given to species that are At Risk or May Be At Risk in the province, that are of uncertain status (Undetermined), or that are considered to be at risk at a national level by the Committee on the Status of Endangered Wildlife in Canada (COSEWIC).

Reports in this series are published and distributed by the Alberta Conservation Association and the Fish and Wildlife Division of Alberta Sustainable Resource Development. They are intended to provide detailed and up-to-date information that will be useful to resource professionals for managing populations of species and their habitats in the province. The reports are also designed to provide current information that will assist Alberta's Endangered Species Conservation Committee in identifying species that may be formally designated as Endangered or Threatened under Alberta's Wildlife Act. To achieve these goals, the reports have been authored and/or reviewed by individuals with unique local expertise in the biology and management of each species. 


\section{EXECUTIVE SUMMARY}

This report synthesizes and analyses information currently available on tiny cryptanthe (Cryptantha minima) - an annual vascular plant species considered as May Be At Risk in Alberta. Tiny cryptanthe, found in Alberta and reported historically in Saskatchewan, was designated as Endangered by the Committee on the Status of Endangered Wildlife in Canada (COSEWIC) in 1997 and 2000. This report, which includes additional, more recent information, including results of field surveys in 2003 and 2004, will be used to more formally evaluate the species' status in Alberta using criteria established by the World Conservation Union (IUCN 2001).

In Alberta, tiny cryptanthe is known only from the vicinity of the lower Bow River and South Saskatchewan River valleys in the Dry Mixedgrass Natural Subregion. The species' habitat is native mixed grasslands in moderately active depositional environments including abandoned sandy terraces on meander lobes in the river valley floodplain, sandy valley slopes, and sand hills near the valley edge. Eighteen subpopulations or occurrences are reported, which make up the known provincial population. Seventeen occurrences are along a 120-km reach of the South Saskatchewan River valley downstream of Medicine Hat and one occurrence is in sand hills near where the Oldman and Bow rivers join to become the South Saskatchewan River, about $105 \mathrm{~km}$ upstream of Medicine Hat. Plant numbers appear to fluctuate greatly from year to year within subpopulations. Occurrence reports range from one individual to tens of thousands of individuals. The known area of occupancy of all reported occurrences is less than $1 \mathrm{~km}^{2}$ and extent of occurrence is less than $2000 \mathrm{~km}^{2}$. One extant occurrence is reported in Saskatchewan near the provincial boundary on a tributary valley of the Red Deer River, about $60 \mathrm{~km}$ from the nearest occurrence in Alberta. The nearest extant population in northeast Montana is $450 \mathrm{~km}$ distant.

A large amount of potential river valley and upland habitat in Alberta has been altered by human activity to the point that it is no longer available for colonization by tiny cryptanthe. Activities include cultivation or seeding to non-native pasture, development of oil and gas well sites, urban and rural residential development, construction of permanent access roads and invasion of native grasslands by non-native plant species. There are specific examples of conversion of native prairie in or near known tiny cryptanthe habitat within the last few years. Further reduction in tiny cryptanthe habitat and area of occupancy is predicted if current trends continue and measures are not taken to identify and protect known subpopulations.

A national recovery strategy for tiny cryptanthe is being developed by a team of federal and provincial representatives. Monitoring and research of tiny cryptanthe in Alberta is recommended, to obtain more complete understanding of the species' habitat requirements and distribution, population size and trends, and the genetic variability and connectivity required to sustain long-term viability of the provincial population. 


\section{ACKNOWLEDGEMENTS}

This report has benefited substantially from the contributions of numerous individuals who generously provided their precious time, unpublished data and answers to many questions. Glennis Lewis and Linda Duncan assisted with fieldwork. Botanists Dana Bush, Nick DeCarlo, Candace Elchuk, Hope Johnson, Ian Macdonald, Dean Nernberg, Bonnie Smith, Cliff Wallis and Cleve Wershler shared the results of their field survey efforts. David Dyer shared information from labels of tiny cryptanthe collections in the University of Montana herbarium. Dennis Baresco provided information on cryptanthe collections in Police Point Park in Medicine Hat. Joyce Gould (Alberta), Clint Emerson (Montana), Bonnie Heidel (Wyoming), Sheila Lamont (Saskatchewan) and Ksenija Vujnovic (Alberta), who work for conservation data centres in their respective jurisdictions, promptly provided information when requested. Robin Gutsell and Joel Nicholson of Alberta Fish and Wildlife and Sue Peters and Nyree Sharp of the Alberta Conservation Association assisted in implementing the 2003 field survey and in preparation of this status report.

Preparation of this report was funded by the Alberta Conservation Association and the Fish and Wildlife Division of Alberta Sustainable Resource Development. 
Digitized by the Internet Archive in 2016 


\section{TABLE OF CONTENTS}

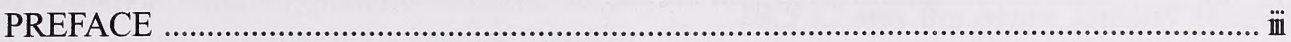

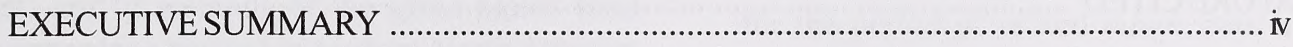

ACKNOWLEDGEMENTS ........................................................................... v

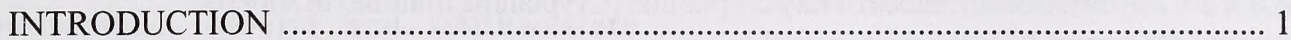

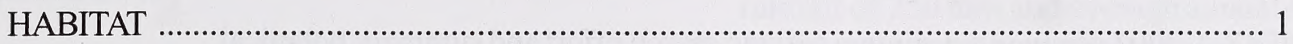

1. Habitat Attributes ........................................................................................ 1

2. River Valley Habitat and Loss ........................................................................ 2

3. Upland Habitat and Loss ......................................................................... 4

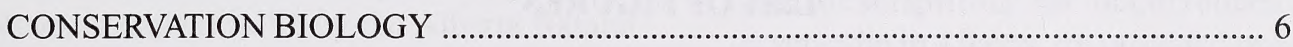

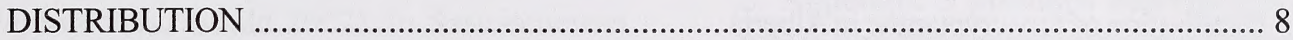

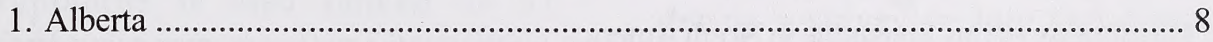

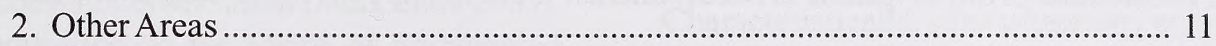

POPULATION SIZE AND TRENDS ....................................................................... 11

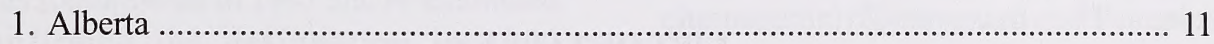

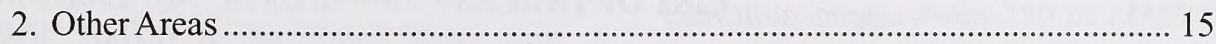

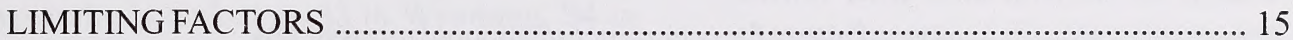

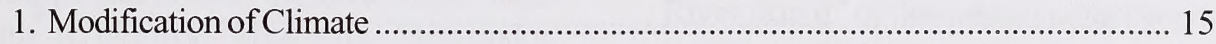

2. Modification of Natural Disturbance Regime ................................................ 15

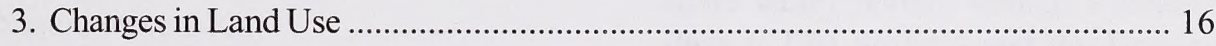

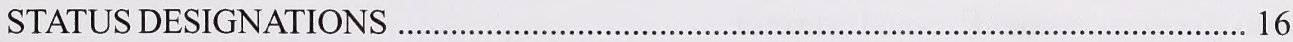

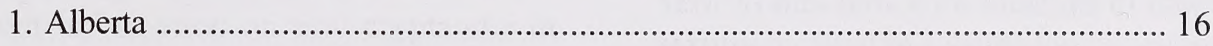

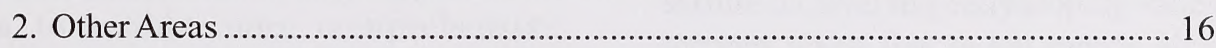

RECENT MANAGEMENT IN ALBERTA _........................................................ 17 
TABLE OF CONTENTS cont.

SYNTHESIS

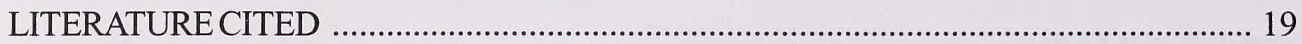

APPENDIX 1 Definitions of selected legal and protective designations. .............................. 24

APPENDIX 2 Confirmed occurrences of tiny cryptanthe (Cryptantha minima) in Alberta (February 2004)

APPENDIX 32003 Cryptantha minima survey: search effort and summary botanical notes by C. Bradley (30 July - 13 August)

\section{LIST OF FIGURES}

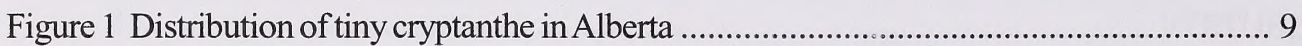

Figure 2 Distribution of tiny crypanthe in North America ..................................................... 12

\section{LIST OF TABLES}

Table 1 Summary of data on number of plants for occurrences/subpopulations of tiny cryptanthe in Alberta. 14 


\section{INTRODUCTION}

Tiny cryptanthe (Cryptantha minima Rydb.), also known as small cryptanthe and little cat'seye, is an annual vascular plant species found in semi-arid grasslands of the great plains (and intermontane basins) of western North America from Texas to Canada. Its known range in Canada is in the dry mixedgrass prairie of southeastern Alberta and southwestern Saskatchewan.

Tiny cryptanthe is considered as May Be At Risk ${ }^{*}$ according to the preliminary general status review of plant species in Alberta (Alberta Sustainable Resource Development 2000a). The species is ranked as S1 by the Alberta Natural Heritage Information Centre (ANHIC) (Vujnovic and Gould 2002). In Saskatchewan, tiny cryptanthe is also ranked as $\mathrm{S} 1$ (Saskatchewan Conservation Data Centre 2003). The Committee on the Status of Endangered Wildlife in Canada (COSEWIC) designated the species as Endangered in 1997 and re-examined and confirmed the designation in 2000 (COSEWIC 2003a). In the United States, tiny cryptanthe is ranked as S3 in Wyoming, S4 in South Dakota and SNR in the seven other states in which it occurs: Montana, Nebraska, Colorado, Kansas, New Mexico, Oklahoma and Texas (NatureServe 2004).

This report compiles and summarizes historical and recent information on tiny cryptanthe in Alberta to enable more comprehensive assessment of provincial status.

\section{HABITAT}

1. Habitat Attributes - In Alberta, tiny cryptanthe is found in the Dry Mixedgrass Natural Subregion of the Grassland Natural Region and is restricted to the vicinity of the South Saskatchewan River valley. The climate is continental, characterized by extremes in

\footnotetext{
* See Appendix 1 for definitions of selected status designations.
}

temperatures with warm summers and cold winters. In the South Saskatchewan River valley at Medicine Hat, the mean July temperature is $19.5^{\circ} \mathrm{C}$ and the mean January temperature is $-10.2^{\circ} \mathrm{C}$ (Environment Canada 2003a). Extremes for the period of record range from a high of $42.2^{\circ} \mathrm{C}$ to a low of $-46.1^{\circ} \mathrm{C}$. Dry summers and winters are typical. Average annual precipitation for the South Saskatchewan River valley at Medicine Hat is $334 \mathrm{~mm}$ with average annual rainfall of $250 \mathrm{~mm}$ and average annual snowfall of $95 \mathrm{~cm}$. Most rainfall occurs in June. Frequently high wind speeds cause high rates of evaporation throughout the summer months.

Site descriptions for occurrences of tiny cryptanthe in Alberta are provided in Appendix 2. Appendix 3 provides descriptions of sites where tiny cryptanthe was sought but not found during a survey in July and August 2003. Characteristically, sites where tiny cryptanthe is found are on poorly developed sandy soils of fluvial or aeolian origin (rego brown chernozems) (Kjearsgaard and Pettapiece 1986). Elevation ranges from $750 \mathrm{~m}(2460 \mathrm{ft})$ in the Lower Bow sand hills on the upland north of the confluence of the Bow River and Oldman River ( $\mathrm{km} 0^{*}$ of the South Saskatchewan River) to $625 \mathrm{~m}(2050 \mathrm{ft})$ in the South Saskatchewan River valley bottom through Canadian Forces Base (CFB) Suffield and the Drowning Ford Grazing Lease. Habitat is generally described as xeric to sub-xeric with substrate of sandy to silty texture on level to gently sloping valley bottom terraces about five to ten metres above mean river level. The origin of these abandoned terraces is attributed to a large, post-glacial river believed to be a precursor to the current South Saskatchewan River (Adams et al. 1997). In addition, tiny cryptanthe has been found on valley slopes with up to $50 \%$ slope, and on undulating to rolling sandy upland near the valley breaks.

\footnotetext{
* River kilometres are based on maps provided in Dickinson and Baresco (1996).
} 
Vegetation communities in which tiny cryptanthe occurs in Alberta are described generally as grasslands dominated by needle-and-thread (Stipa comata) and blue grama (Bouteloua gracilis) grass. Commonly associated species include prickly pear (Opuntia polycantha), Indian rice grass (Oryzopsis hymenoides), low sedge (Carex stenophylla), Pursh's plantain (Plantago patagonica), silver sagebrush (Artemesia cana) and winter-fat (Eurotia lanata). Usually there is 10 to 30 percent bare soil. Some sites are described as disturbed and associated with pipelines and vehicle or livestock trails through native vegetation.

In Saskatchewan, the habitat for tiny cryptanthe, based on one occurrence, is described as a southfacing valley slope with sandy loam substrate. Vegetation is dominated by needle-and-thread grass and Dakota goosefoot (Chenopodium dacoticum) with $30 \%$ to $40 \%$ bare soil (Saskatchewan Environment 2003, C. Elchuk pers. comm.).

In the United States, tiny cryptanthe is found on plains and intermontane basins east of the continental divide of the Rocky Mountains. Habitat is generally characterized as dry grassland on sandy or gravelly (talus) substrate in valley bottoms, at the base of sandstone and limestone outcrops, lower valley slopes, on plains and on stabilized or active sand dunes (Correll and Johnston 1970, McGregor et al. 1986, University of Colorado 2004, D. Dyer pers. comm., B. Heidel pers. comm.). Besides occurring in grasslands, tiny cryptanthe also occurs in shrublands dominated by sand sage (Artemesia filifolia) or big sage (Artemesia tridentata) and in open ponderosa pine (Pinus ponderosa) woodland. Roadsides and reservoir margins also are mentioned as habitats. Botanists studying vegetation in southwest Kansas and southeast Colorado found tiny cryptanthe on prairie dog (Cynomys ludovicianus) colonies and not on adjacent non-colonized short-grass prairie (Winter et al. 2002).
A common attribute of habitats for tiny cryptanthe appears to be that the sites have been subjected to moderately active depositional processes through the action of water (sandy river terraces), gravity (lower slopes, midslope benches), wind (sand dunes and plains) or shortterm soil-disturbing activities of animals (prairie dogs, large herbivores) or humans. Substrates on which this annual species establishes are generally sorted and coarse in texture, and are composed of silty sands, sands or mixed sands and gravels rather than unsorted tills or deposits rich in clays and organic matter. Tiny cryptanthe does not appear to occupy habitats experiencing active erosion (cutbanks, eroding valley slopes) or intense and repeated disturbance (active point bars, cultivated fields). It also has not been found in vegetation communities with high canopy cover, high litter and little exposed soil. Opening of the vegetation canopy through natural processes (drought, fire, grazing) or human disturbances (establishing trails, mowing) appears to stimulate germination of seeds in the seedbank or provide a seedbed free of competition where plants can establish, but tiny cryptanthe is not associated with sites that have been compacted (well sites, roads) or where there is major alteration of native vegetation (seeded pasture). Livestock grazing may help maintain populations of tiny cryptanthe as has been shown in studies of the effects of grazing on annual plants (Osem et al. 2002, Hayes and Holl 2003). Further study would be required to determine what factors or combination of environmental factors benefit tiny cryptanthe, such as availability of moist bare sites for seed germination, rapid drainage, absence of soil compaction, absence of litter, exposure to sunlight, and lack of competition with other plant species for space and nutrients or minerals.

2. River Valley Habitat and Loss - Most known occurrences of tiny cryptanthe in Alberta are in river valley habitat, on second- or third-level terraces $5 \mathrm{~m}$ to $10 \mathrm{~m}$ above river level (Appendix 2). These terraces were deposited by a larger 
post-glacial river (Adams et al. 1997). Over the last 100 years, these habitats have experienced little, if any, flooding. Tiny cryptanthe was also found on valley slopes of south, east and west aspects with up to $50 \%$ slope and on adjacent upland within a few hundred metres of the valley edge.

The 51-km reach of the South Saskatchewan River valley in which tiny cryptanthe has been found in the valley bottom ( $\mathrm{km} 157$ to $\mathrm{km} \mathrm{208)}$ has a broad valley across which the river channel moves, creating large meander lobes. CFB Suffield flanks the valley on the west, and public lands under lease to the Drowning Ford Grazing Association border it on the east. Large portions of terraces on some meander lobes in this reach have been converted to crested wheat grass (Agropyron pectiniforme) pasture (Appendix 3). Tiny cryptanthe was found only in native mixed grassland and not in areas converted to nonnative pasture. Crested wheat grass appears to be persisting and expanding into native vegetation. It is known to persist for several decades on mixedgrass prairie sites where it has been seeded, particularly on regosol and brown chernozem soils, and has been documented invading native grassland communities (Bush 2001, Bradley 2003, Henderson et al. in press).

All meander lobes on which tiny cryptanthe was found within the Drowning Ford Grazing Lease also have active gas well sites and access roads where vegetation had been removed (Appendix $3)$. At one site there is a gravel pit. Tiny cryptanthe was absent from the areas that receive repeated disturbance or compaction even when present immediately adjacent to them. Tiny cryptanthe was found in areas of native vegetation on and adjacent to a pipeline rightof-way on the valley slope (Appendix 2).

A 67-km reach of the South Saskatchewan River upstream of CFB Suffield to Redcliff (km 90 to $\mathrm{km} \mathrm{157)}$ can also be characterized as a broad valley across which the river channel moves creating large meander lobes. Observations from accessible viewpoints of the valley top indicated that all meander lobes in this reach have been altered to some extent by cultivation, irrigation and human settlement. Two meander lobes at $\mathrm{km} 148$ and $\mathrm{km} 156$ were searched on foot; tiny cryptanthe was not found (Appendix 3). The meander lobes have been largely converted to irrigated cropland, and remaining fragments of native vegetation are experiencing salinization from increased moisture and conversion to species associated with mesic habitats. Tiny cryptanthe was found on valley slopes and nearby uplands at $\mathrm{km} 110$ and $\mathrm{km} 112$ but not on adjacent river valley terraces, which have been mostly converted to irrigated cropland and urban residential development (Appendix 2). Terraces within Police Point Park in Medicine Hat (km 105 to km 109) still support substantial areas of native grassland vegetation; however, tiny cryptanthe has not been found in vegetation surveys (Appendix 3, D. Baresco pers. comm.). Although river valley habitat in this reach appears to have been suitable for tiny cryptanthe at one time, there is low potential for extant populations because of the high level of conversion of native vegetation to non-native cropland and pasture and human settlement.

The $90-\mathrm{km}$ reach of the South Saskatchewan River upstream of Redcliff ( $\mathrm{km} 0$ to $\mathrm{km} 90$ ) has a narrow valley and the channel is of low sinuosity and often confined by bedrock. There are a few meander lobes with fluvial terraces of low slope. The large majority of quarter sections in this reach are mapped by the native prairie vegetation baseline inventory as having less than $75 \%$ native vegetation (Alberta Sustainable Resource Development 2000b). Uplands south of the river valley are largely cultivated and under irrigation. Tiny cryptanthe was not found during a 1996 survey of the Express Pipeline crossing in this reach (AXYS 1996). Investigations of valley bottom terraces on meanders near the Grand Forks found large areas that had annual crops under irrigation or had been converted to non-native pasture (Appendix $3)$. Invasion of native grassland fragments by 
non-native species is occurring. No tiny cryptanthe was found. This reach is considered to have low potential for supporting populations of tiny cryptanthe.

Downstream of CFB Suffield to the provincial boundary, for $89 \mathrm{~km}$ ( $\mathrm{km} 212$ to $\mathrm{km} \mathrm{301),} \mathrm{the}$ valley of the South Saskatchewan River is narrow and the channel is confined by bedrock through most of its length. Meander lobe habitat for tiny cryptanthe is scarce. No tiny cryptanthe was found in rare plant surveys annually in 2000 to 2003 along the North Suffield Pipeline routing where it crosses the South Saskatchewan River valley (AXYS 2002). In 2003, areas of potential valley bottom habitat for tiny cryptanthe were searched on foot, including meander lobes near Sandy Point (km 263 and $\mathrm{km} 270$ to $\mathrm{km} \mathrm{276)}$ and at the Saskatchewan border ( $\mathrm{km} 291$ to $\mathrm{km}$ 301). Tiny cryptanthe was not found (Appendix 3). Portions of the meander lobes near Sandy Point have been converted to non-native vegetation through cultivation, recreation site development, water pump installation and roads and facilities associated with major natural gas pipeline construction. A large meander loop straddling the provincial boundary remains largely native vegetation and appears to have suitable habitat; however, searches in 2002 and 2003 failed to find tiny cryptanthe (Appendix $3)$.

To summarize, about $50 \%(145 \mathrm{~km})$ of the length of the South Saskatchewan River valley in Alberta historically had suitable meander lobe habitat for tiny cryptanthe. Since the early 1900s, most of the potential meander lobe habitat has been altered to the point that it no longer is suitable for sustaining viable populations of tiny cryptanthe. Most of this habitat loss is on private land; however, river valley habitat under public ownership also has been cultivated or seeded to non-native pasture. Most of the remaining suitable meander lobe habitat lies within a 58$\mathrm{km}$ reach $(\mathrm{km} 156$ to $\mathrm{km} \mathrm{214)}$ bounded on the west by CFB Suffield (a portion within the recently designated National Wildlife Area) and on the east by public lands of the Drowning Ford Grazing Lease. A large meander loop straddling the provincial boundary also appears to remain as potential habitat. Valley slopes with appropriate habitat characteristics, however, still support or have the potential to support tiny cryptanthe.

3. Upland Habitat and Loss - Tiny cryptanthe was first found in upland habitat in Alberta in 2002, in an area known as the Lower Bow dunes about $7 \mathrm{~km}$ upstream of where the Bow and Oldman rivers join to form the South Saskatchewan River, known as Grand Forks (Appendix 2). The site is $1 \mathrm{~km}$ north of a tributary valley to the Bow River and $3 \mathrm{~km}$ north of the Bow River valley. In 2003, two occurrences of tiny cryptanthe were reported on sandy upland of the public lands leased to the Drowning Ford Grazing Association in the vicinity of previously documented river valley occurrences. In 2004, tiny cryptanthe was found in stabilized sand dunes of the Middle Sand Hills about $2 \mathrm{~km}$ west of the South Saskatchewan River valley breaks (D. Nernberg pers. comm.). Also in 2004, tiny cryptanthe was found in undulating sand hills within $1 \mathrm{~km}$ west of the South Saskatchewan River valley breaks in the city of Medicine Hat (D. Nernberg pers. comm.).

Tiny cryptanthe has not been found in several previous surveys of potentially suitable upland habitat in southern Alberta. For example, surveys of sand hill and sand plain habitat in the Mixedgrass Natural Subregion and Dry Mixedgrass Natural Subregion of southern Alberta in 1987 did not find tiny cryptanthe (Wallis and Wershler 1988). Areas surveyed included Remount-Empress, Hilda, Matzhiwin, Suffield, Old Channel Lake, Brooks-Vauxhall, Barnwell, Little Rolling Hills, Lake Newell, Lower Bow, Lost River, Pakowki Lake and Wildhorse-Manyberries (including Lost River). Surveyors reported that Fendler's cryptanthe (Cryptantha fendleri) was locally common. Tiny cryptanthe also was not found during several subsequent surveys of sand hill and sand plain 
habitat for other plant species at risk, including smooth goosefoot (Chenopodium subglabrum) (Smith and Bradley 1992), western spiderwort (Tradescantia occidentalis) (Smith 2001) and small-flowered sand-verbena (Tripterocalyx micranthus) (Alberta Sustainable Resource Development 2003). In addition, tiny cryptanthe was not found in annual vegetation surveys during 2000 to 2003 of the North Suffield Pipeline Project routing through the Middle Sand Hills (AXYS 2002).

Two intensive vegetation surveys of portions of CFB Suffield by experienced botanists in 19941995 and 2003 did not find tiny cryptanthe in upland habitat, although two plants were found about $9 \mathrm{~km}$ apart in river valley habitat (Macdonald 1997, Environment Canada 2003b, I. Macdonald pers. comm.) (Appendix 2). A search of sand hills near Purple Springs and Hilda in 2003 failed to find tiny cryptanthe (Appendix 3).

To ascertain whether there is suitable habitat for tiny cryptanthe on the uplands between currently known occurrences, C. Bradley examined soil maps for the presence of sandy soils, acted on by wind or water, which are found on coarsetextured parent material of aeolian or fluvial origin (Kjearsgaard and Pettapiece 1986). Coarse-textured fluvial or aeolian parent materials are common along both sides of the South Saskatchewan River between Medicine Hat and the Saskatchewan border, generally occurring within $5 \mathrm{~km}$ of the valley breaks. Included in this band are the Middle Sand Hills, which are largely within the eastern portion of CFB Suffield and are now designated as a national wildlife area. There are a few small scattered patches of sandy soils in the western portion of CFB Suffield and in the area west toward the Lower Bow Dunes; however, the large majority of parent materials are fine- to medium-textured calcareous till (Kjearsgaard and Pettapiece 1986). Most of the area east of the South Saskatchewan River to the provincial boundary also is underlain by fine- to mediumtextured calcareous till inconsistent with tiny cryptanthe habitat. Significant portions of these uplands are under cultivation (Alberta Sustainable Resource Development 2000b).

In Alberta, native prairie is estimated to have declined by 60 to 70 percent since colonization in the late 1890 s, as a result of human activities including cultivation, roads and urbanization (Alberta Environmental Protection 1997, Alberta Sustainable Resource Development 2000b). Grasslands in Alberta are in decline with the Dry Mixedgrass Natural Subregion containing most of what is left. However, native prairie in this subregion is also under threat.

The total amount of native prairie remaining in the Dry Mixedgrass Natural Subregion, based on interpretation of 1991-1993 aerial photography, is estimated at 54\% (2 $576667 \mathrm{ha}$ ) (Alberta Sustainable Resource Development 2000b). This implies a decline of $46 \%$ over 100 years. Actual rate of decline of native prairie could be higher, as the interpretation of aerial photography does not allow the interpreter to ascertain which "grasslands" are dominated by non-native species. More detailed inventory and tracking of changes in the amount of native prairie are proposed (Prairie Conservation Forum 2001).

The degree of fragmentation of grasslands in the Dry Mixedgrass Natural Subregion is high. Aerial photo interpretation of the amount of prairie remaining by quarter section found that only $33 \%$ of quarter sections have $76-100 \%$ native prairie, $14 \%$ of quarter sections have 51 $75 \%$ native prairie and the remainder (55\%) have less than $50 \%$ native prairie (Alberta Environmental Protection 1997). Relatively large parcels of native grasslands include those portions of the South Saskatchewan River valley and adjacent uplands where tiny cryptanthe has been found in Alberta (Alberta Sustainable Resource Development 2000b).

Specific to the Lower Bow location for tiny cryptanthe, native prairie on sand plain about $10 \mathrm{~km}$ east was cultivated for potato production 
in 2003 (Bray and Wallis 2003). No survey information for rare plant species is available for this site prior to cultivation.

Native prairie in the Grassland Natural Region is becoming increasingly fragmented not only by cultivation but also by development of oil and gas well sites, country residential subdivision and development and roads. In 1993, there were 51931 oil and gas well sites in the Dry Mixedgrass Natural Subregion for an average density of 1.11 well sites $/ \mathrm{km}^{2}$ or 103 well sites per township (Alberta Environmental Protection 1997). Major oil and gas fields include Grand Forks and Suffield (including public lands under lease to the Drowning Ford Grazing Association), both areas of known habitat for tiny cryptanthe in Alberta.

The number of well sites within potential habitat for tiny cryptanthe has continued to increase over the last decade. For example, the "Forks" area at the confluence of the Bow and Oldman Rivers, including the Lower Bow Dunes site for tiny cryptanthe, has seen a rapid increase in oil and gas well sites and access roads since the early 1980 s. In a $15-\mathrm{km}^{2}$ area just north of the confluence, about 50 well sites and $50 \mathrm{~km}$ of access roads were constructed between 1977 and 1998 (Prairie Conservation Forum 2003). This rapid rate of fragmentation is also occurring on the public lands under lease to the Drowning Ford Grazing Association (C. Bradley pers. obs., J. Nicholson pers. comm.). Activity proceeds without rare plant inventory. These developments not only remove native vegetation but also provide avenues for invasion of aggressive non-native plant species into native prairie.

Specific to the Medicine Hat location for tiny cryptanthe, recent urban residential development has eliminated a portion of the subpopulation, thereby fragmenting it into two subpopulations. The development occurred prior to documentation of the tiny cryptanthe subpopulation within the city. The remainder of the subpopulation on the upland in Medicine Hat is threatened by planned urban residential expansion (D. Nernberg pers. comm.).

A project to model the cumulative environmental effects of human activities in the Grassland Natural Region using the landscape simulator ALCES has led participants to the following conclusion: "If we factor in future land deletions caused by the expansion of settlements, energy development, agricultural production and transportation networks, we will see a gradual reduction in native prairie through time" (Prairie Conservation Forum 2003). Conservative projections are that 1000 ha of native prairie will be lost each year, resulting in a 25 percent reduction in native prairie over the next 100 years (Prairie Conservation Forum 2003). More than double that amount of loss is predicted if current rates of expansion of the human footprint continue.

A conclusion from the information provided in this section is that a large portion of potential native upland and river valley habitat for tiny cryptanthe has been lost owing to human activity over the last century, and substantial further loss is predicted if current trends in land use continue without measures being taken to identify and protect sites where tiny cryptanthe occurs.

\section{CONSERVATION BIOLOGY}

Tiny cryptanthe, also known as small cryptanthe, little cryptanthe or little cat's-eye, is an annual vascular plant species in the borage family (Boraginaceae). Annual plants only grow for one year and a large portion of their life cycle is as seed.

The type specimen of tiny cryptanthe was collected in Colorado in 1900 and described by the American botanist Rydberg in 1901 (New York Botanic Garden 1901). The stem of the plant is branched from near the base. The bristlyhairy branches can reach $20 \mathrm{~cm}$ in height and often are prostrate. The leaves are bristly-hairy, alternate, with blunt tips and tapered bases, and 
linear, up to $3 \mathrm{~cm}$ long and $0.5 \mathrm{~cm}$ wide. The small white flowers are tube-like with lobes at right angles at the top and a yellow "eye" in the centre. They measure up to $3 \mathrm{~mm}$ long and $2 \mathrm{~mm}$ across. The flowers can be present in up to two-thirds of the plant's height, on one side of the uncoiling branches. The sepals enlarge to about $5 \mathrm{~mm}$ long when the plant is in fruit and have veins that are whitish, thick and hard. Each flower (or fruit) has a leaf-like bract below it on the stem. The fruits are four whitish nutlets. They are of two sizes, with one nutlet being smooth and larger ( $2 \mathrm{~mm} \times 1.2 \mathrm{~mm}$ ) and the other three being rough (with bumps) and smaller $(1.5 \mathrm{~mm}$ $\mathrm{x} 0.9 \mathrm{~mm}$ ). The odd nutlet is more firmly attached to the base (receptacle) than the other three.

Tiny cryptanthe superficially resembles two other species, Fendler's cryptanthe and Kelsey's cat's-eye (Cryptantha kelseyana). Fendler's cryptanthe has branches arising closer to the top of the stem, bracts only under the lowest flowers and smooth-sided nutlets. Kelsey's cat's-eye also has bracts only under the lowest flowers but its nutlets are similar to those of tiny cryptanthe, with one larger and smooth and three smaller and rough; however, the midrib of the calyx is not as thick as in tiny cryptanthe. Fendler's cryptanthe is a common species in sand dune areas in southern Alberta whereas Kelsey's cat'seye has only recently been documented as occurring in the province. Tiny cryptanthe occurs in habitats that also may support Fendler's cryptanthe and Kelsey's cat's-eye. Close examination is required to differentiate the species.

In Alberta, tiny cryptanthe has been found flowering in late June and early July. Reproduction is sexual. Agents for pollination are unknown; hence, the minimum distance that one tiny cryptanthe plant must be to another for cross-pollination to occur is also unknown. As well, it is not know what factors affect seed production in tiny cryptanthe.
Fruits of tiny cryptanthe mature in late July and August in Alberta. It is likely that most of the small seeds of tiny cryptanthe are dispersed close to the parent plant; however, a small proportion may be dispersed further by the action of wind, water or animals (birds, mammals, insects) digging or walking (Primack and Miao 1992, Murphy and Lovett-Doust 2004). Annual and short-lived plant species generally are adapted to germinate on bare soil. Persistence of an occurrence of tiny cryptanthe or establishment of a new occurrence therefore partly depends on having suitable bare soil habitat accessible to dispersing seeds (Harrison et al. 2000, Freckleton and Watkinson 2002).

Of the seeds produced each year by annual plants such as tiny cryptanthe, some are non-viable, some are lost to seed predators, some form seedlings and some are stored in the seed bank for germination in a future year. Seed bank and germination ecology are especially important to annual plants, but information on these topics is extremely difficult and time-consuming to gather; therefore, little is known (Elzinga et al. 1998). For example, it is not known what proportion of tiny cryptanthe seeds is stored in the seed bank or for how long seeds remain viable. As a general rule, annual plants depend on seed longevity to buffer their populations against environmental unpredictabilities (Harper 1977). It is not known what conditions stimulate germination of tiny cryptanthe seeds.

Many species of annual plants experience large flushes of germination when conditions are right, which may occur as infrequently as once in a decade or more (Elzinga et al. 1998). Plant numbers may fluctuate wildly from year to year depending on the seed production in previous years, germination of seedlings, and environmental conditions, such as the timing and amount of rainfall (Bush and Lancaster in press). As well, there may be random environmental influences, such as weather, habitat changes, herbivores and fire or flood that affect growth 
and survival of plants once germination occurs. Subpopulations may disappear and others appear (Harrison et al. 2000). There is some evidence that such large fluctuations are characteristic of tiny cryptanthe (see Population Size and Trends section).

In summary, very little is known about the life cycle and ecology of tiny cryptanthe. Challenges to monitoring populations and evaluating their potential viability are greater for annual plants, such as tiny cryptanthe, than for perennial species because traditional demographic approaches, which consider age or stage class and rates of mortality, recruitment, or growth, are not appropriate (Elzinga et al. 1998).

\section{DISTRIBUTION}

1. Alberta - All reports of tiny cryptanthe in Alberta are along the South Saskatchewan River valley (except for one report along the Bow River valley) within the Dry Mixedgrass Natural Subregion of the Grassland Natural Region. Eighteen occurrences are identified in Appendix 2 and mapped in Figure 1. These occurrences have been documented by several botanists and are contained in the records of the Alberta Natural Heritage Information Centre (ANHIC). For the purposes of this document an occurrence is defined as the location of a subpopulation, which is consistent with the definition used by ANHIC (J. Gould pers. comm.). Subpopulations are defined as geographically or otherwise distinct groups in the population between which there is little known exchange, of either pollen or seed (IUCN 2001). For annual plants, subpopulations are separated by distances of a few hundred metres and more because longdistance dispersal of plant seed beyond a few hundred metres is rare (Cain et al. 2000). A population is the total number of individuals in the province.

The first Alberta report of tiny cryptanthe is based on a collection by John Macoun made on 2 June 1894 near the "police barracks, Medicine Hat." The collection is filed with the Canadian
Museum of Nature National Herbarium (1894; Macoun \#5803, CAN 93956). The collection was made before formal description of the species in 1901. The three specimens on the herbarium sheet were identified by Macoun as Krynitzia crassisepala, which today is known as thick sepal cryptanthe (Cryptantha crassisepala), a species of the southern U.S. Great Plains. The specimens later were revised by F. Johnston to be in part tiny cryptanthe (C. minima) and in part Kelsey's cat's-eye (C. kelseyana). In 1964, the identification of specimens was revised to Fendler's cryptanthe (C. fendleri) by H.G. Scoggan who notes in The Flora of Canada that the identification requires clarification (Scoggan 1979). C. Bradley examined the specimens in May 2004 and determined that the one specimen with nutlets is $C$. kelseyana but the other two specimens are too immature for positive identification. Later botanical surveys of Police Point Park in Medicine Hat- the site of the old North West Mounted Police barracks — including the 2003 survey by C. Bradley, failed to find tiny cryptanthe (D. Baresco pers. comm.). In 2004, however, large numbers of $C$. minima and C. kelseyana were reported on valley slopes and sandy uplands $1 \mathrm{~km}$ northwest of Police Point Park (D. Nernberg pers. comm., Appendix 2). This likely is the subpopulation sampled by the 1894 collections.

The second Alberta report of tiny cryptanthe was in 1973, at km 164 (SS6) on the west side of the South Saskatchewan River near the southern boundary of Suffield Military Reserve, about 55 $\mathrm{km}$ downstream of Medicine Hat. There is some uncertainty about the precise location. A specimen was collected by Hope Johnson in late July and had mature fruits, allowing positive identification.

Following this discovery, the species appeared in a supplement to the Flora of Alberta (Packer 1974) and a decade later was listed in A Checklist of the Rare Vascular Plants in Alberta (Packer and Bradley 1984) and in the revised Flora of 


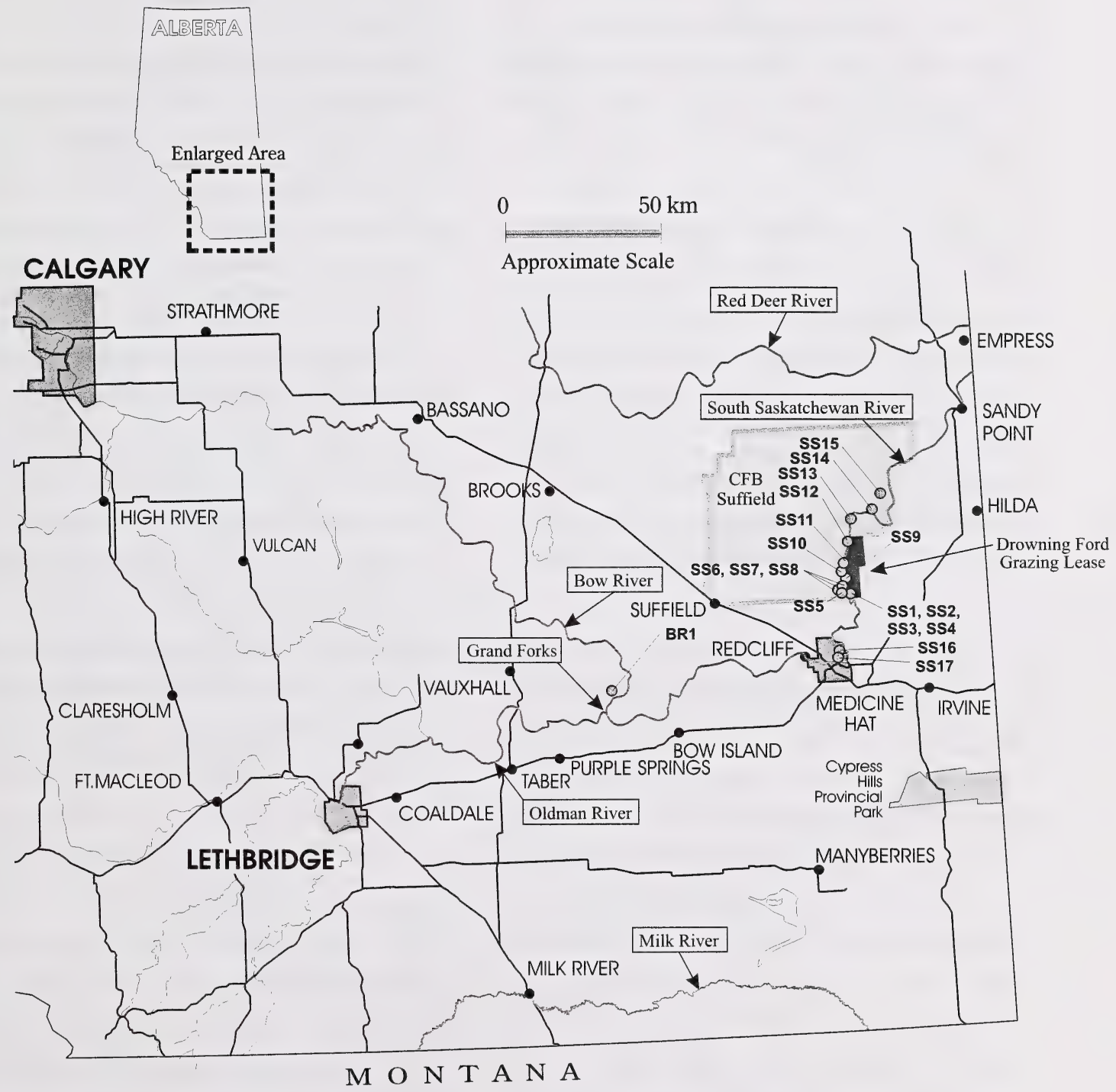

Figure 1. Distribution of tiny cryptanthe in Alberta. Numbers correspond to site numbers in Appendix 2. 
Alberta (Moss 1984), prompting botanists to search for additional occurrences during vegetation surveys. In 1994, an individual tiny cryptanthe plant was found at km 208 (SS14) during a rare plants survey within the proposed National Wildlife Area on CFB Suffield (Macdonald 1997). In 1998, another individual was found during a rare plant survey of a proposed pipeline route crossing at $\mathrm{km} 158$ (SS2a), on public land leased to the Drowning Ford Grazing Association (D. Bush pers. comm.).

In 2002, tiny cryptanthe was reported in the Lower Bow dunes (BR1), near where the Bow and Oldman rivers merge to form the South Saskatchewan River, over $155 \mathrm{~km}$ upstream of the nearest previously reported occurrence (B. Smith pers. comm.). Two occurrences also were reported within $1 \mathrm{~km}$ of each other, near $\mathrm{km} 157$ (SS1a) and km 158 (SS2b), where a proposed pipeline right-of-way crossed the South Saskatchewan River valley. One of these, SS2b, coincides with the 1998 occurrence (D. Bush pers. comm.).

In 2003, eleven occurrences of tiny cryptanthe were reported during two surveys. One rare plant survey focused search effort in the National Wildlife Area of CFB Suffield on the west side of the South Saskatchewan River and reported one individual tiny cryptanthe plant at $\mathrm{km} 208$ (SS14) (I. Macdonald pers. comm.). The other survey was conducted by C. Bradley along the South Saskatchewan River outside of CFB Suffield, from the river's origin at the Forks near Bow Island to the Saskatchewan border. The survey specifically focused on tiny cryptanthe. Eleven occurrences of tiny cryptanthe were reported between $\mathrm{km} 157$ and $\mathrm{km} \mathrm{190.} \mathrm{Two} \mathrm{of}$ these occurrences were in locations where subpopulations had been previously reported (SS1b and SS2c) and nine were in locations where subpopulations had not been previously reported (SS3, SS4, SS5, SS7, SS8, SS9, SS10, SS11, SS12) (Appendix 2).
A 1996 collection of a cryptanthe near Empress on the Red Deer River was initially reported as tiny cryptanthe but in 2003 it was re-identified as Kelsey's cat's-eye (B. Smith pers. comm.), the first confirmed record of that species in Alberta. In 2002, a cryptanthe species, initially identified as tiny cryptanthe, was found along a pipeline right-of-way at $\mathrm{km} 263$, on the upland and at the base of the valley slope (N. DeCarlo pers. comm.). It has tentatively been re-identified as Kelsey's cat's-eye by C. Bradley. In 2003, river valley terraces in the Red Deer River valley near Empress and $3 \mathrm{~km}$ upstream were surveyed by C. Bradley (Appendix 3). Tiny cryptanthe was not found; however, Kelsey's cat's-eye was found on a disturbed site corresponding to the 1996 occurrence. In 2004, three additional occurrences of tiny cryptanthe were reported, one in the Middle Sandhills of CFB Suffield and the other two within $1 \mathrm{~km}$ of each other on sandy uplands and valley slopes in Medicine Hat.

In summary, 18 occurrences make up the known population of tiny cryptanthe in Alberta. Seventeen occurrences are within a $120-\mathrm{km}$ reach of the South Saskatchewan River downstream of Medicine Hat between km 110 and $\mathrm{km} 230$ (Figure 1, SS1-17). Distances between known occurrences in this reach vary from a few hundred metres to about $20 \mathrm{~km}$. One occurrence is highly disjunct from the others, located $75 \mathrm{~km}$ directly southwest in dunes along the lower Bow River valley just upstream of its confluence with the Oldman River (Figure 1, BR1). Given that there is no information on genetic exchange among known occurrences and that long-distance dispersal of plant seed beyond a few hundred metres is rare (Cain et al. 2000), it is recommended for the purposes of status assessment that these occurrences be considered subpopulations. Subpopulations are defined as geographically or otherwise distinct groups in the population between which there is little exchange (typically one successful migrant individual or gamete per year or less) (IUCN 2001). Further study would be required to confirm this conclusion. 
There has been substantial search effort for rare vascular plant species in sand dune and sand hill habitat in southeastern Alberta as described in Wallis and Wershler (1988), Smith and Bradley (1992), Macdonald (1997), Smith (1997), Smith (2001), Alberta Sustainable Resource Development (2003) and in Appendix 2 and Appendix 3. These sources also contain documentation of some search effort in the South Saskatchewan and Red Deer river valleys. In addition there have been several rare plant surveys along proposed pipeline routings through sand dune and sand hill habitat and crossing river valleys. Therefore, there is some degree of confidence that the provincial distribution mapped in Figure 1 is truly representative of the actual distribution. A caution that must be placed on this conclusion, however, is that tiny cryptanthe is an annual plant which may or may not be found during surveys even though it may be present in the seed bank. More systematic monitoring of known locations and searching of suitable habitat over several years are required to verify the provincial distribution.

The extent of occurrence of the tiny cryptanthe in Alberta can be calculated in two ways. One is to make a polygon by drawing straight lines between the most northerly, westerly, southerly and easterly occurrences. The area circumscribed by this polygon is about $1600 \mathrm{~km}^{2}$. Alternatively, it could be assumed that the polygon representing extent of occurrence can be defined as the Bow and South Saskatchewan river valleys and adjacent uplands from Lower Bow Dunes to $\mathrm{km}$ 230, a total distance of about $235 \mathrm{~km}$. Valley length is about $190 \mathrm{~km}$, less than channel length because of channel sinuosity. Assuming an average valley width of about $3 \mathrm{~km}$ to include valley bottom, slopes and adjacent uplands, extent of occurrence is about $570 \mathrm{~km}^{2}$.

Area of occupancy, defined as the area within the extent of occurrence that is occupied by tiny cryptanthe excluding unsuitable or unoccupied habitats (IUCN 2001), is about $820000 \mathrm{~m}^{2}$, slightly less than $1 \mathrm{~km}^{2}$, based on information provided in Appendix 2 and Table 1. The loss of the Medicine Hat population to urban residential development would result in a $30 \%$ decline in known area of occupancy of the Alberta population.

2. Other Areas - In Saskatchewan, there is one known extant occurrence of tiny cryptanthe on the slopes of a tributary valley of the Red Deer River $2 \mathrm{~km}$ east of the border with Alberta (C. Elchuk pers. comm.). Its area of occupancy is reported as about $2800 \mathrm{~m}^{2}$. There is also a 1981 collection from this location (Smith 1997). A collection in 1977 near the town of Westerham ( $25 \mathrm{~km}$ east of the provincial border and $5 \mathrm{~km}$ south of the South Saskatchewan River) was identified as tiny cryptanthe (Smith 1997). Subsequent surveys of this location, however, have not found tiny cryptanthe but report an abundance of Fendler's cryptanthe and some Kelsey's cat's-eye, which are similar in appearance to tiny cryptanthe (S. Lamont pers. comm., C. Elchuk pers. comm.).

The closest known extant occurrence of tiny cryptanthe in the United States is Sheridan County in northeast Montana, about $450 \mathrm{~km}$ southeast of the Alberta range (B. Heidel pers. comm.) (Figure 2). The range of the species extends south through the plains of eastern Montana and Wyoming, the southwest corner of South Dakota, western Nebraska and Kansas, the eastern plains of Colorado and some western intermontane basins, eastern New Mexico, the panhandles of Oklahoma and Texas and south in western Texas to Mexico. The species' range in Canada is less than one percent of its continental range.

\section{POPULATION SIZE AND TRENDS}

1. Alberta - The population of annual plants, such as tiny cryptanthe, consists not only of the plants that are rooted and growing but also of the buried viable seed (Harper 1977). Determining population size, therefore, requires not only counting the number of plants on the 


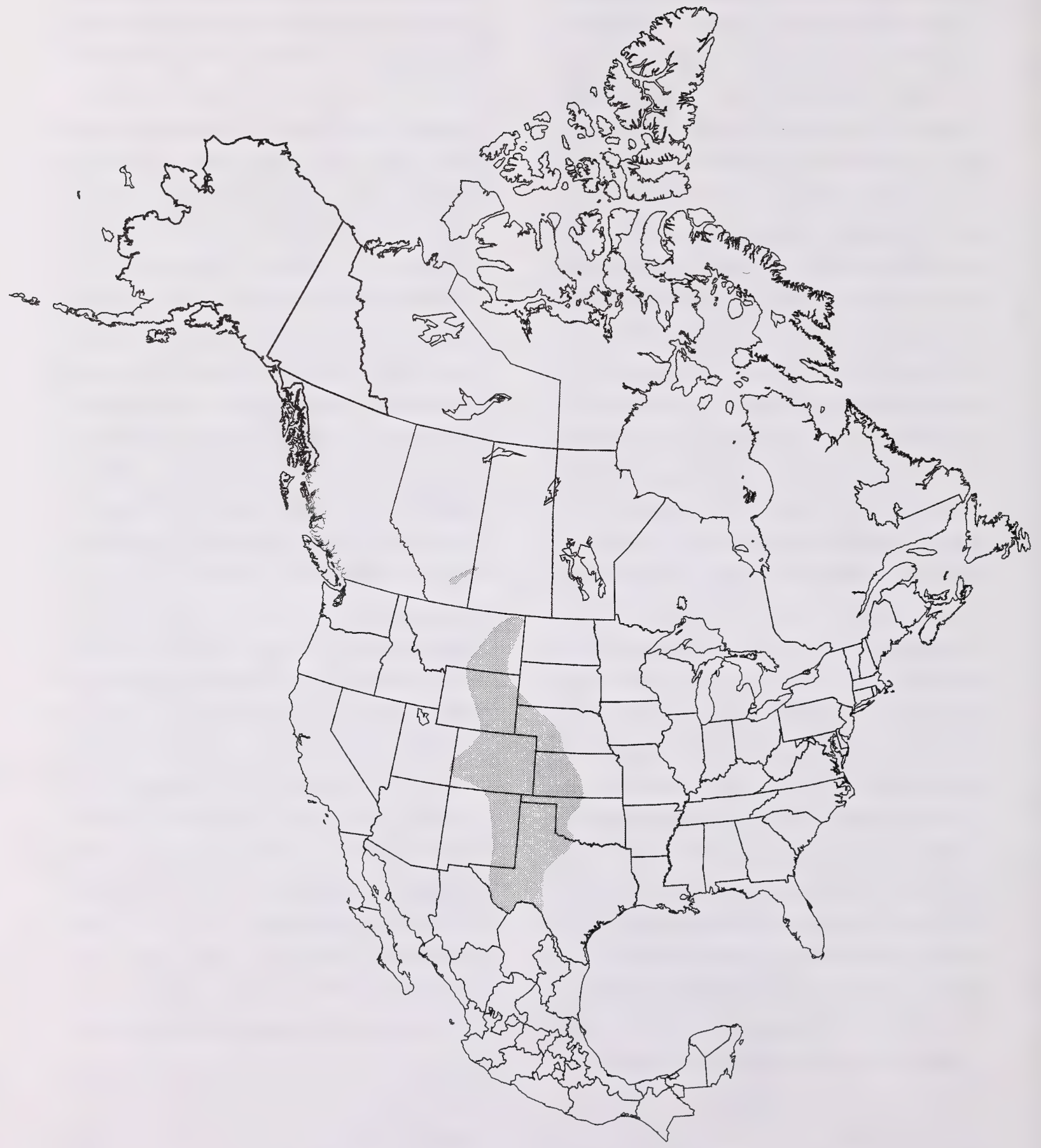


surface but also analyzing the size and viability of the seed bank using techniques that extract soil cores and use flotation to separate the seeds for counting or grow out the cores in a greenhouse (Elzinga et al. 1998). As well, given that the seed bank may represent an accumulation of seeds from many previous generations, determining fluctuations or trends in population size requires that cohorts of new additions be distinguished from the bulk accumulated from the past. Harper (1977) refers to this as a "hidden overlap of generations." Furthermore, germination can be spatially variable from year to year; hence, permanent plots may be of little value unless they are designed to capture changes in location of disturbance patches. Nonetheless, counts of mature plants in a location where they have been previously reported can be undertaken to determine germination and establishment in a given year, to assess factors which promote germination and establishment, and to assist in evaluating the status of subpopulations over time and their significance for the larger population (Elzinga et al. 1998, Morris et al. 1999).

Data available for number of tiny cryptanthe plants associated with reported occurrences in Alberta are presented in Table 1. For some subpopulations, plant numbers are provided for more than one year. These data were collected by a variety of botanists for various purposes using different techniques and in different years. Number of mature individuals reported for any one occurrence varies from 1 to estimates of 50000 . These data are provided as preliminary information but are insufficient for assessing the size of the provincial population because they have been obtained without systematic survey methodology and without standardized sampling techniques, represent only a small number of years and do not consider seed bank.

The data suggest that plant numbers of tiny cryptanthe fluctuate greatly from year to year. For example, at the Lower Bow Dunes site (BR1) no plants were found in surveys in 1987 ,
2001, 2003 or 2004; however, in 2002, 62 plants were counted in a $5 \mathrm{~m} \mathrm{x} 8 \mathrm{~m}$ area (Wallis and Wershler 1988, Alberta Sustainable Resource Development 2003, Appendix 2). Similarly, at $\mathrm{km} 157$ on the South Saskatchewan River (SS1), tiny cryptanthe was found at a density of 0.06 plants $/ \mathrm{m}^{2}$ in 2002 and at an average density of 0.23 plants $/ \mathrm{m}^{2}$ in 2003 (Appendix 2). At km 198 on the South Saskatchewan River (SS2), 1 plant was found in 1998, no plants were found in 1999 or 2000, 74 plants were found in 2002 and 170 plants were found in 2003 (Appendix 2).

Although different survey techniques by different botanists may account for some of the fluctuation in plant numbers from year to year, this fluctuation is also indicative of the biological characteristics of annual species. Many species of annual plants experience large flushes of germination when conditions are right, which may occur with a frequency of every few years or perhaps once in a decade or more (Elzinga et al. 1998, Bush and Lancaster in press). Hence, plant numbers may fluctuate wildly from year to year depending on the seed production in previous years, germination of seedlings, and environmental conditions, such as the timing and amount of rainfall.

Since challenges of monitoring annual plant populations are so great, management objectives may be better focused on habitat features such as level of human activity, invasion of exotics and other changes in plant community composition caused by succession or alteration in natural disturbance regime (Elzinga et al. 1998).

Noteworthy is that the predicted loss of the large Medicine Hat subpopulation of tiny cryptanthe (SS16) to planned urban residential development would result in immediate loss of a seed bank capable of producing 50000 mature individuals in one year-a subpopulation three times the size of the next largest annual subpopulation of mature individuals previously reported in Alberta (SS7). 
Table 1. Summary of data on number of plants for occurrences/subpopulations of tiny cryptanthe in Alberta. (see Figure 1 for occurrence locations; see Appendices 2 and 3 for site descriptions and more details)

\begin{tabular}{|c|c|c|c|c|}
\hline $\begin{array}{l}\text { Occurrence/ } \\
\text { Subpopulation }\end{array}$ & Date & \# Plants & Area $\left(\mathrm{m}^{2}\right)$ & $\begin{array}{c}\text { Density } \\
\text { (plants } / \mathrm{m}^{2} \text { ) }\end{array}$ \\
\hline \multirow[t]{5}{*}{ BR1 } & 1987 & Not found & $\mathrm{n} / \mathrm{a}$ & - \\
\hline & 2001 & Not found & $\mathrm{n} / \mathrm{a}$ & - \\
\hline & 12 Jul 2002 & 62 & 40 & 1.55 \\
\hline & $30 \mathrm{Jul} 2003$ & Not found & $\mathrm{n} / \mathrm{a}$ & - \\
\hline & 9 Jul 2004 & Not found & $\mathrm{n} / \mathrm{a}$ & - \\
\hline \multirow[t]{3}{*}{ SS1 } & 1998 & Not found & $\mathrm{n} / \mathrm{a}$ & - \\
\hline & 16 Jul 2002 & 160 & 2500 & 0.06 \\
\hline & 1 Aug 2003 & $11500 *$ & 50000 & 0.23 \\
\hline \multirow[t]{5}{*}{ SS2 } & 3 Jul 1998 & 1 & $\mathrm{n} / \mathrm{a}$ & - \\
\hline & 1999 & Not found & $\mathrm{n} / \mathrm{a}$ & - \\
\hline & 2000 & Not found & $\mathrm{n} / \mathrm{a}$ & - \\
\hline & 15 Jul 2002 & 74 & $\mathrm{n} / \mathrm{a}$ & - \\
\hline & 4 Aug 2003 & 170 & 5000 & 0.03 \\
\hline SS3 & 4 Aug 2003 & 555 & 5000 & 0.11 \\
\hline SS4 & 4 Aug 2003 & Numerous & $\mathrm{n} / \mathrm{a}$ & - \\
\hline SS5 & 5 Aug 2003 & 110 & 4000 & 0.03 \\
\hline \multirow[t]{2}{*}{ SS6 } & 22 Jul 1973 & 2 & $n / a$ & - \\
\hline & Aug 2003 & Not found & $\mathrm{n} / \mathrm{a}$ & - \\
\hline SS7 & 5 Aug 2003 & $17500^{*}$ & 250000 & 0.07 \\
\hline \multirow[t]{2}{*}{ SS8 } & 5 Aug 2003 & several & $\mathrm{n} / \mathrm{a}$ & - \\
\hline & $10 \mathrm{Jul} 2004$ & 80 & 80 & 1.00 \\
\hline SS9 & 5 Aug 2003 & 12 & 120 & 0.10 \\
\hline SS10 & 10 Aug 2003 & $7500 *$ & 250000 & 0.03 \\
\hline SS 11 & 11 Aug 2003 & 37 & 25 & 1.40 \\
\hline SS12 & 11 Aug 2002 & 2 & 3 & 0.67 \\
\hline SS13 & 22 Jul 2003 & 1 & $\mathrm{n} / \mathrm{a}$ & - \\
\hline SS14 & 7 Jul 1994 & 1 & $\mathrm{n} / \mathrm{a}$ & - \\
\hline SS15 & 14 Jul 2004 & 399 & 300 & 1.33 \\
\hline SS16 & 10 Aug 2004 & $50000 *$ & 250000 & 0.20 \\
\hline SS17 & 15 Aug 2004 & $500^{*}$ & 5000 & 0.10 \\
\hline
\end{tabular}

* indicates that values are estimates based on subplot counts and estimated extent. 
2. Other Areas - In Saskatchewan, the one known extant population of tiny cryptanthe was estimated to be 12000 plants in 2004 (C. Elchuk pers. comm.). An expanded search of the area would likely have resulted in more mature plants being reported (C. Elchuk pers. comm.). No other data are available on population size or trends in that province.

There is no known effort throughout the species' range in the United States to document population size or trends in population of tiny cryptanthe (C. Emerson pers. comm., B. Heidel pers. comm.).

\section{LIMITING FACTORS}

Limiting factors discussed in this report are major factors that affect habitat quality and availability, reproductive output, or survival of individuals. The focus is on factors that have an anthropogenic origin. Three major limiting factors have been identified by C. Bradley: modification of climate, modification of natural disturbance regime and changes in land use.

\section{Modification of Climate - The reason(s) why} tiny cryptanthe occurs in Alberta but is confined to the vicinity of the South Saskatchewan River valley (and Bow River valley) probably relates to climate. The core of the species' range comprises hotter and drier environments in the central Great Plains of the western United States (Figure 2). Perhaps tiny cryptanthe colonized southern Alberta during a period of warmer and drier climate and, as climate cooled, persisted in that portion of Alberta where climate is most similar to that in the core range. The international scientific community has concluded that there is compelling evidence that human activity, particularly activities associated with energy use and deforestation, is accelerating the concentration of greenhouse gases in our atmosphere and that climate change is a likely consequence accompanied by largely unpredictable impacts on the earth's ecosystems (Government of Canada 2002). A shift to a warmer climate may result in expansion of the species' range provincially, provided that there is not significant disruption of the native habitats in which it occurs and that the frequency of successful seed production and germination events is adequate. A rapid shift to a cooler climate could lead to extirpation of tiny cryptanthe from Alberta. Either way, climate change introduces considerable uncertainty regarding the species' survival.

\section{Modification of Natural Disturbance Regime}

- Tiny cryptanthe appears to be adapted to habitats of sandy substrate, with varying amounts of silt, that experience disturbance. Its affinity to sandy river terraces and undulating or rolling sand dunes, stabilized or not, suggests a reliance on wind shifting sand to create and maintain suitable habitat. Its affinity to habitats in dips and benches on valley slopes may indicate a reliance on slope wash to create openings for establishment and persistence. Drought and fire may play important roles in removing canopy vegetation to promote germination or in destabilizing sandy substrates to create new sites for establishment. Finally, tiny cryptanthe's association with trails and mounds of burrowing mammals suggests an adaptation to the disturbance processes associated with the activities of native animals, such as ground squirrels and bison. Today, domestic livestock mimic to some extent the historic role of bison in the prairie ecosystem.

If a disturbance regime is modified beyond the range of natural variability, consequences for native species can be expected (Bradley and Wallis 1996). For example, climate change or water management that reduces periodic large floods and inhibits channel migration could havenegative implications for the creation and maintenance of tiny cryptanthe habitat. Stabilization of sand dunes through fire suppression could also have negative effects. Elimination of burrowing mammals as a result of pest control programs or complete removal of large grazing animals from the grassland ecosystem also have the potential for negative effects on habitat for tiny cryptanthe. 
3. Changes in Land Use - Information on past and predicted changes in land use since the early 1900 s within the range of tiny cryptanthe in Alberta is provided in the Habitat section of this report. Key conclusions include the following:

- Most of the potential meander lobe habitat in the South Saskatchewan River valley has been altered by cultivation or seeding to nonnative pasture and by invasion of non-native plant species to the point that it is no longer considered suitable habitat for tiny cryptanthe.

- Native prairie on uplands in the Dry Mixedgrass Natural Subregion, including sand plain and sand hill habitats suitable for tiny cryptanthe, has declined by at least $46 \%$ over the last century due to cultivation. Considerably more suitable habitat has been fragmented by roads, residential development and oil and gas well sites, which not only remove native vegetation but also provide avenues for invasion by aggressive non-native plant species.

- Modelling of the cumulative environmental effects of human activities predicted in the Grassland Natural Region over the next 100 years suggests further reduction in native prairie by between 25 and 50 percent.

- There are specific examples of conversion of native prairie in or near known tiny cryptanthe habitat within the past 10 years including cultivation of sandy $\mathrm{p}^{1}$ ain for potato production in the Lower Bow area, urban residential expansion in Medicine Hat, and rapid development of oil and gas wells and access roads in the Lower Bow, Suffield and Drowning Ford Grazing Lease areas.

Alberta's tiny cryptanthe population is small in extent of occurrence and area of occupancy. It is disjunct by $60 \mathrm{~km}$ from the only population known in Saskatchewan and by $450 \mathrm{~km}$ from the nearest known extant population in Montana. Little genetic exchange between subpopulations separated even by a few hundred metres is expected. Direct loss of even one subpopulation of tiny cryptanthe in Alberta and isolation of subpopulations through further fragmentation of suitable habitat can result in a provincial population so reduced in genetic resources and connectivity that the long-term viability of the provincial population is threatened.

\section{STATUS DESIGNATIONS*}

1. Alberta - Tiny cryptanthe is considered as May Be At Risk according to the preliminary general status review of plant species in Alberta (Alberta Sustainable Resource Development 2000a). Considerations that went into the assessment in the late 1990s were that the species had been assessed as endangered nationally, there were few reported occurrences in Alberta hence very little was known about population size and distribution, and petroleum and natural gas activities were a threat to its known habitat.

The Alberta Natural Heritage Information Centre (ANHIC) database has ranked tiny cryptanthe as $\mathrm{S} 1$ since the provincial vascular plant tracking list was first compiled in 1996. ANHIC botanists and an advisory group of professional botanists review rankings periodically and until the present have chosen to maintain the S1 rank given that five or fewer occurrences are reported and only a few individuals were associated with each occurrence (Vujnovic and Gould 2002). Threat to the species' habitat from oil and gas development activity also was a consideration.

Information from a variety of rare plant surveys since 2002 has greatly increased our knowledge about tiny cryptanthe in Alberta. The information is summarized in this report, which will be used to evaluate the provincial status of the species.

2. Other Areas - The Committee on the Status of Endangered Wildlife in Canada designated tiny cryptanthe as Endangered in 1998 based on a status report submitted in January 1997 (Smith 1997). COSEWIC re-examined the report and

* See Appendix 1 for definitions of selected status designations. 
confirmed the designation in May 2000 using revised IUCN criteria (COSEWIC 2003a). The species qualified for Endangered status because the known population at that time in Canada was fewer than 250 individuals (IUCN criterion D1). Low relative mobility and distance from nearby populations were considered to likely limit the rate of exchange with populations in the United States hence ranking was not downgraded. This report provides substantially more information on occurrences of tiny cryptanthe in Canada than was contained in the 1997 report.

Globally, tiny cryptanthe (also known as little cat's-eye) is ranked as G5, meaning that there are more than 100 occurrences and/or it is demonstrably secure (NatureServe 2004). Its national heritage status rank in the United States is NNR, meaning that tiny cryptanthe has not yet been ranked nationally (NatureServe 2004). In Canada, the national heritage status rank is N1 (22 March 1989) (NatureServe 2004). In Saskatchewan, tiny cryptanthe is ranked as S1 (Saskatchewan Conservation Data Centre 2003). Tiny cryptanthe is ranked as S3 in Wyoming, S4 in South Dakota and SNR in the seven other states in which it occurs: Montana, Nebraska, Colorado, Kansas, New Mexico, Oklahoma and Texas (NatureServe 2004). The species is widely distributed in most of these states; hence the SNR ranking may indicate that the species is not considered at risk and has not been a priority for ranking (McGregor et al. 1986, University of Wyoming 1998, New Mexico Natural Heritage Program 2004, Texas A\&M University Bioinformatics Working Group 2004, United States Department of Agriculture 2004, University of Colorado 2004, C. Emerson pers. comm., B. Heidel pers. comm.). In the Great Plains of the United States, state-wide estimates of mixedgrass prairie habitat loss since presettlement times range from a low of 30 percent in Texas to as high as 75 percent in Nebraska, suggesting threats to tiny cryptanthe habitat similar to those in Canada (Bachand 2001).

\section{RECENT MANAGEMENT IN ALBERTA}

Tiny cryptanthe is listed as Endangered in Schedule 1 of the federal Species at Risk Act (Government of Canada 2004). Three Alberta occurrences are within the Suffield National Wildlife Area, which is managed as a protected wildlife area under federal jurisdiction. A national recovery strategy is in development by a recovery team that includes representatives from Environment Canada, Agriculture and Agri-Food Canada, Department of National Defence (CFB Suffield), Alberta Sustainable Resource Development, Saskatchewan Environment, Manitoba Conservation and the Canadian Cattlemen's Association (R. Gutsell pers. comm.).

\section{SYNTHESIS}

Tiny cryptanthe (Cryptantha minima) is an annual species found in the vicinity of the lower Bow River and South Saskatchewan River valleys in the Dry Mixedgrass Natural Subregion of southeastern Alberta. Its habitat is moderately active depositional environments on sandy meander lobe terraces in the river valley floodplain, sandy valley slopes, and sand hills near the valley edge. Eighteen subpopulations are recognized: 17 are found along a $120-\mathrm{km}$ reach of the South Saskatchewan River extending downstream from Medicine Hat through CFB Suffield (west side) and public rangelands leased by the Drowning Ford Grazing Association (east side), and one subpopulation is widely disjunct, occurring on public land in the Lower Bow sand hills. The extent of occurrence of the species in Alberta is estimated at $570 \mathrm{~km}^{2}$ or $1600 \mathrm{~km}^{2}$ using two different methodologies, and the known area of occupancy is less than $1 \mathrm{~km}^{2}$.

The results of substantial search efforts to date, and analysis of maps of soils and land use, indicate that the species is unlikely to occur in the river valley and uplands between the Lower 
Bow sand hills and Medicine Hat. A few additional subpopulations may be found in and along the South Saskatchewan River valley downstream of Medicine Hat; however, their discovery would be unlikely to increase either the known area of occupancy or population size significantly. More structured and systematic surveys would be needed to confirm this conclusion. Most potential meander lobe habitat in the South Saskatchewan River valley has been altered by cultivation or seeding to non-native pasture and by invasion of non-native plant species to the point that it is no longer available for colonization by tiny cryptanthe. Upland habitat has experienced similar pressures. There are specific examples of conversion of native prairie in or near known tiny cryptanthe habitat within the last few years. Modelling of the cumulative environmental effects of human activities predicted in the Grassland Natural Region over the next 100 years suggests further reduction in native prairie between 25 and 50 percent should current trends continue. Other potential limiting factors are modification of the natural disturbance regime and modification of climate.

Estimates of plant numbers of tiny cryptanthe at the 18 known occurrences range from 1 to 50000 plants and suggest large fluctuations depending on the seed production in previous years, germination of seedlings, and environmental conditions, such as the timing and amount of rainfall. This fluctuation is characteristic of annual plant species, which spend a large part of their life cycle as seeds. To get a better understanding of the number of subpopulations, their distribution, annual fluctuations, trends and factors that affect survival, it is necessary to implement a standardized monitoring methodology of known occurrences and suitable habitat over several years.

Alberta's tiny cryptanthe population is small in extent of occurrence and area of occupancy. It is disjunct by $60 \mathrm{~km}$ from the only population known in Saskatchewan and by $450 \mathrm{~km}$ from the nearest population in Montana. Little genetic exchange between subpopulations separated even by a few hundred metres is expected. Tiny cryptanthe is designated as Endangered by COSEWIC, first in 1998 and reassessed in 2000 (COSEWIC 2003a), and is listed in Schedule 1 of the federal Species at Risk Act (Government of Canada 2004). A national recovery strategy is being developed. Direct loss of even one subpopulation of the current population of tiny cryptanthe in Alberta and further isolation of subpopulations through fragmentation of suitable habitat could result in reductions in genetic resources and connectivity to the point that the long-term viability of the provincial population is threatened. 


\section{LITERATURE CITED}

Adams, G. D., G. C. Trottier, W. L. Strong, I. D. Macdonald, S. J. Barry, P. G. Gregoire, G. W. Babish and G. Weiss. 1997. Vegetation component report, Canadian Forces Base Suffield National Wildlife Area Wildlife Inventory. Canadian Wildlife Service, Edmonton, AB. 96 pp.

Alberta Environmental Protection. 1996. The status of Alberta wildlife. Alberta Environmental Protection, Natural Resources Service, Wildlife Management Division. Edmonton, AB. 44 pp.

Alberta Environmental Protection. 1997. The Grassland Natural Region of Alberta: one of a series of reports prepared for the Special Places 2000 Provincial Coordinating Committee. Natural Heritage Protection and Education Branch. Edmonton, AB. 229 pp.

Alberta Forestry, Lands and Wildlife. 1991. The status of Alberta wildlife. Alberta Forestry, Lands and Wildlife, Fish and Wildlife Division. Edmonton, AB. 49 pp.

Alberta Natural Heritage Information Centre (ANHIC). 2002. Rank Definitions. URL: http://www.cd.gov.ab.ca/preserving/ parks/anhic/definitions.asp [Last Updated: October 2002].

Alberta Sustainable Resource Development. 2000a. Vascular plants: 2000 preliminary general status ranks for Alberta. Unpublished report. Fish and Wildlife Division. Edmonton, AB.

Alberta Sustainable Resource Development. 2000b. Native Prairie Vegetation Baseline Inventory. Resource Data Branch. URL: http:// www.albertapcf.ab.ca/background.htm. [Date Accessed: May 2, 2004].
Alberta Sustainable Resource Development. 2001. The general status of Alberta wild species 2000. Alberta Sustainable Resource Development, Fish and Wildlife Service, Edmonton, AB. 46 pp.

Alberta Sustainable Resource Development. 2003. Status of the small-flowered sand verbena (Tripterocalyx micranthus) in Alberta. Alberta Sustainable Resource Development, Fish and Wildlife Division, and Alberta Conservation Association. Wildlife Status Report No. 48. Edmonton, AB. 44 pp.

AXYS Environmental Consulting Ltd. 1996. Vegetation assessment for the proposed Express Pipeline Projects. Prepared for Express Pipeline Ltd. 18 pp + appendices (240 pp).

AXYS Environmental Consulting Ltd. 2002. Rare plant monitoring survey for the North Suffield Pipeline Project. Prepared for Encana Suffield Gas Pipeline Inc. 18 pp. + appendices (14 pp).

Bachand, R. R. 2001. The American prairie: going, going, gone? A status report on the American prairie. National Wildlife Federation, Boulder CO. URL: www.nwf.org. [Date Accessed: May 2, 2004]

Bradley, C. 2003. Invasion of non-native plant species: report on workshop results. Report for the Southern Alberta Sustainability Strategy. Alberta Environment, Lethbridge, AB. 23pp.

Bradley, C., and C. Wallis. 1996. Prairie ecosystem management: an Alberta perspective. Prairie Conservation Forum Occasional Paper \#2. 32 pp.

Bray, S., and C. Wallis. 2003. Was the trade of native prairie for potato production a good one? Wildlands Advocate 11(6):19. 
Bush, D. 2001. Crested wheatgrass invasion on native prairie. Iris, the newsletter of the Alberta Native Plant Council, No. 40, Summer 2001. Edmonton, AB. 1 p.

Bush, D., and J. Lancaster. in press. Rare annual plants - problems with surveys and assessments. Paper presented to the $7^{\text {th }}$ Prairie Conservation on Endangered Species Conference (28 Feb 2004). Calgary, AB.

Cain M.L., B.G. Milligan and A.D. Strand. 2000. Long-distance seed dispersal in plant populations. American Journal of Botany 87: 1217-1227.

Canadian Museum of Nature National Herbarium. 1894. Collection \#5803 by John Macoun.

Correll, D.S., and M.C. Johnston. 1970. Manual of the vascular plants of Texas. Texas Research Foundation. Renner, Texas. $1881 \mathrm{pp}$

COSEWIC. 2003a. COSEWIC assessment results, November 2003. Committee on the Status of Endangered Wildlife in Canada. $44 \mathrm{pp}$. URL: http:// www.cosewic.gc.ca/htmlDocuments/ sar_2003_11_e.htm [Date Accessed: May 2, 2004]

COSEWIC. 2003b. Database. Committee on the Status of Endangered Wildlife in Canada. URL: http://www.cosewic.gc.ca [Last Updated: August 2003].

Dickinson, D., and D. Baresco. 1996. Prairie River: a canoe and wildlife viewing guide to the South Saskatchewan River from Grand Forks, Alberta to Estuary, Saskatchewan. Holmes Printing. Medicine Hat, AB. 150 pp.

Elzinga, C., D. Salzer and J. Willoughby. 1998. Measuring and monitoring plant populations. Bureau of Land Management Technical Reference 17301. Denver, Colorado. 477 pp.

Environment Canada. 2003a. Canadian climate normals: 1971-2000. URL:http:// www.climate.weatheroffice.ec.gc.ca/ climate_normals. [Last updated: February 28, 2004]

Environment Canada. 2003b. Inventory of the proposed national wildlife area on Canadian Forces Base Suffield: vegetation component summary and vascular flora component summary. Summary of the results of a study funded by Canadian Wildlife Service and Department of National Defence in 1994-1995.

URL:http:// www.mb.ec.gc.ca/nature/whp/nwa/ suffield/dd02s03.en.html. [Last updated: April 8, 2004]

Freckleton, R.P., and A.R. Watkinson. 2002. Large-scale spatial dynamics of plants: metapopulations, regional ensembles and patchy populations. Journal of Ecology 90:419-434.

Government of Canada. 2002. Climate change plan for Canada. URL: http:// www.climatechange.gc.ca/ plan_for_canada/climate/kyoto.html. [Last updated: November 26, 2002]

Government of Canada. 2004. Species At Risk Act Public Registry. URL: http:// www.sararegistry.gc.ca/default_e.cfm . [Last updated: April 21, 2004]

Harper, J. L. 1977. Population biology of plants. Academic Press, New York. 892 pp.

Harrison, S., J. Maron and G. Huxel. 2000. Regional turnover and fluctuation in populations of five plants confined to serpentine seeps. Conservation Biology 14(3): 769-779. 
Hayes, G.F. and K.D. Holl. 2003. Cattle grazing impacts on annual forbs and vegetation composition of mesic grasslands in California. Conservation Biology 17(6): 1694-1702.

Henderson, D., C.E. Parker and M.A. Naeth. in press. Landscape influences on alien grass invasions in the prairie ecozone. Paper presented to the 7 th Prairie Conservation and Endangered Species Conference (28 Feb 2004). Calgary, AB.

IUCN. 2001. IUCN Red List Categories and Criteria: Version 3.1. IUCN Species Survival Commission. IUCN, Gland, Switzerland and Cambridge,UK. ii +30 pp.

Kjearsgaard, A.A., and W.W. Pettapiece. 1986. Soils of the Medicine Hat area (72L/NE, 72L/SE, 72L/SW). Agriculture Canada, Research Branch, Land Resource Research Centre, Edmonton, AB. Map scale 1:126 720. LRRC contributions 9026, 90-27.

Macdonald, I. 1997. Vascular plant flora component report, Canadian Forces Base Suffield National Wildlife Area Wildlife Inventory. Canadian Wildlife Service, Edmonton, AB. 209 pp.

McGregor, R.L., T.M. Barkley, R.E. Brooks and E.K. Schofield. 1986. Flora of the Great Plains. University Press of Kansas. Lawrence, Kansas. 1392 pp.

Morris, W., D. Doak, M. Groom, P. Kareiva, J. Fieberg, L. Gerber, P. Murphy and D. Thomson. 1999. A practical handbook for population viability analysis. The Nature Conservancy, Santa Barbara, California. $80 \mathrm{pp}$.

Moss, E.H. 1984. Flora of Alberta. Second edition, revised by John G. Packer.
University of Toronto Press, Toronto, Canada. 687 pp.

Murphy, H.T., and J. Lovett-Doust. 2004. Context and connectivity in plant metapopulations and landscape mosaics: does the matrix matter? Oikos 105: 314.

National Research Council. 1995. Science and the Endangered Species Act. National Academy Press, Washington, DC. 271 pp.

NatureServe. 2004. NatureServe Explorer: An online encyclopedia of life [web application]. Version 3.0. Arlington, Virginia, USA: NatureServe. URL: http:/ /www.natureserve.org/explorer/ index.htm. [Last updated: July 1, 2004]

New Mexico Natural Heritage Program. 2004. UNM herbarium specimen information. URL: http://nmnhp.unm.edu/partners/ $\mathrm{msb} /$ herbarium. [Last updated: October 24, 2001]

New York Botanic Garden. 1901. Collection \#00335178. Cryptantha minima specimen collected by P.A. Rydberg and F.K. Vreeland, Cuchara River CO, May 31, 1900. URL: http://sidsite.nybg.org/ herbim/2820/v-282-00335178big.jpg. [Date accessed: May 2, 2004]

Osem Y., A. Perevolotsky and J. Kigel. 2002. Grazing effect on diversity of annual plant communities in a semi-arid rangeland: interactions with small-scale spatial and temporal variation in primary productivity. Journal of Ecology (90): 936-946.

Packer, J.G. 1974. A supplement to E.H. Moss's flora of Alberta. University of Toronto Press, Toronto, Canada. 31 pp. 
Packer, J.G., and C. E. Bradley. 1984. A checklist of the rare vascular plants in Alberta. Provincial Museum of Alberta Natural History Occasional Paper No. 5. Edmonton, AB. 112 pp.

Prairie Conservation Forum. 2001. Alberta Prairie Conservation Action Plan: 20012005. Published by the Prairie Conservation Forum, Lethbridge, AB. 34 pages.

Prairie Conservation Forum. 2003. Prairie environment series: grassland cumulative effects. Presentation. URL: http://www.albertapcf.ab.ca/ PPT_Info.htm. [Date accessed: May 2, 2004]

Primack, R.B., and S.L. Miao. 1992. Dispersal can limit local plant distribution. Conservation Biology 6(4): 513-519.

Saskatchewan Conservation Data Centre. 2003. Tracked species list for vascular plants. URL: http://www.biodiversity.sk.ca/ Docs/vasctrak.pdf. [Last updated: November 27, 2003]

Saskatchewan Environment. 2003. Tiny cryptanthe (Cryptantha minima) fact sheet. Includes range maps for Saskatchewan and North America. URL: http://www.se.gov.sk.ca/ecosystem/ speciesatrisk/tinycrypanthe.htm. [Date accessed: May 2, 2004]

Scoggan, H.J. 1979. The flora of Canada, Part 4: Dicotyledoneae (Loasaceae to Compositae). National Museums of Canada, Ottawa, Canada. Pp.1117-1711.

Smith, B. 1997. Status report on species at risk in Canada: tiny cryptanthe (Cryptantha minima). Committee on the Status of Endangered Wildlife in Canada. 24 pp.
Smith, B. 2001. Status of the western spiderwort (Tradescantia occidentalis) in Alberta. Alberta Environmental Protection, Fisheries and Wildlife Management Division, and Alberta Conservation Association. Wildlife Status Report No. 31. Edmonton, AB. 12 pp.

Smith, B., and C. Bradley. 1992. Status report on the smooth goosefoot, Chenopodium subglabrum, in Canada. Committee on the Status of Endangered Wildlife in Canada. 34 pp.

Texas A\&M University Bioinformatics Working Group. 2004. TAMU-BWG Herbarium Specimen Browser. URL: http:// www.csdl.tamu.edu/FLORA/tracy/ main1.html. [Date accessed: May 4, 2004]

University of Colorado. 2004. Specimen database of Colorado vascular plants. Botany Section, Museum. URL: http:// cumuseum.colorado.edu/Research/ Botany/Databases/search.php. [Date accessed: May 2, 2004]

University of Wyoming. 1998. Atlas of the vascular flora of Wyoming. Rocky Mountain Herbarium. URL: http:// www.esb.utexas.edu/tchumley/wyomap/ BOR/crymin.pdf. [Date accessed: May 2, 2004]

United States Department of Agriculture. 2004. Plants database. Natural Resources Conservation Service. URL:http:// plants.usda.gov. [Last updated: April 30, 2004]

Vujnovic, K., and J. Gould. 2002. Alberta Natural Heritage Information Centre tracking and watch lists-vascular plants, mosses, liverworts and hornworts. Alberta Community 
Development, Parks and Protected Areas

Division. Edmonton. 36 pp.

Wallis, C., and C. Wershler. 1988. Rare wildlife and plant conservation studies in sandhill and sand plain habitats of southern Alberta. Alberta Forestry, Lands and Wildlife, Alberta Recreation and Parks and World Wildlife Fund Canada. Edmonton, AB. 161 pp.

Winter S.L., J.F. Cully Jr. and J.S. Pontius. 2002. Vegetation of prairie dog colonies and non-colonized short-grass prairie. Journal of Range Management 55:502508. 
Appendix 1. Definitions of selected legal and protective designations.

A. The General Status of Alberta Wild Species 2000 (after Alberta Sustainable Resource Development 2001)

\begin{tabular}{|c|c|c|}
\hline 2000 Rank & 1996 Rank & Definitions \\
\hline At Risk & Red & $\begin{array}{l}\text { Any species known to be At Risk after formal detailed status } \\
\text { assessment and designation as Endangered or Threatened in } \\
\text { Alberta. }\end{array}$ \\
\hline May Be At Risk & Blue & $\begin{array}{l}\text { Any species that may be at risk of extinction or extirpation, and is } \\
\text { therefore a candidate for detailed risk assessment. }\end{array}$ \\
\hline Sensitive & Yellow & $\begin{array}{l}\text { Any species that is not at risk of extinction or extirpation but may } \\
\text { require special attention or protection to prevent it from becoming } \\
\text { at risk. }\end{array}$ \\
\hline Secure & Green & Any species that is not At Risk, May Be At Risk or Sensitive. \\
\hline Undetermined & $\begin{array}{l}\text { Status } \\
\text { Undetermined }\end{array}$ & $\begin{array}{l}\text { Any species for which insufficient information, knowledge or data } \\
\text { is available to reliably evaluate its general status. }\end{array}$ \\
\hline Not Assessed & $\mathrm{n} / \mathrm{a}$ & $\begin{array}{l}\text { Any species known or believed to be present but which has not yet } \\
\text { been evaluated. }\end{array}$ \\
\hline Exotic/Alien & $\mathrm{n} / \mathrm{a}$ & $\begin{array}{l}\text { Any species that has been introduced as a result of human } \\
\text { activities. }\end{array}$ \\
\hline Extirpated/Extinct & $\mathrm{n} / \mathrm{a}$ & $\begin{array}{l}\text { Any species no longer thought to be present in Alberta } \\
\text { (Extirpated) or no longer believed to be present anywhere in the } \\
\text { world (Extinct). }\end{array}$ \\
\hline Accidental/Vagrant & $\mathrm{n} / \mathrm{a}$ & $\begin{array}{l}\text { Any species occurring infrequently and unpredictably in Alberta, } \\
\text { i.e., outside its usual range. }\end{array}$ \\
\hline
\end{tabular}

\section{B. Alberta Wildlife Act/Regulation}

Species designated as Endangered under Alberta's Wildlife Act include those listed as Endangered or Threatened in the Wildlife Regulation.

\begin{tabular}{|l|l|}
\hline Endangered & A species facing imminent extirpation or extinction. \\
\hline Threatened & A species that is likely to become endangered if limiting factors are not reversed. \\
\hline
\end{tabular}

\section{Committee on the Status of Endangered Wildlife in Canada (after COSEWIC 2003b)}

\begin{tabular}{|l|l|}
\hline Extinct & A species that no longer exists. \\
\hline Extirpated & A species that no longer exists in the wild in Canada, but occurs elsewhere. \\
\hline Endangered & A species facing imminent extirpation or extinction. \\
\hline Threatened & A species that is likely to become endangered if limiting factors are not reversed. \\
\hline Special Concern & $\begin{array}{l}\text { A species of special concern because of characteristics that make it particularly } \\
\text { sensitive to human activities or natural events. }\end{array}$ \\
\hline Not at Risk & A species that has been evaluated and found to be not at risk. \\
\hline Data Deficient & $\begin{array}{l}\text { A species for which there is insufficient scientific information to support status } \\
\text { designation. }\end{array}$ \\
\hline
\end{tabular}


Appendix 1 continued.

D. Heritage Status Ranks: Global (G), National (N), Sub-National (S) (after Alberta Natural Heritage Information Centre 2002, NatureServe 2004)

\begin{tabular}{|l|l|}
\hline G1/N1/S1 & $\begin{array}{l}5 \text { or fewer occurrences or only a few remaining individuals. May be especially } \\
\text { vulnerable to extirpation because of some factor of its biology. }\end{array}$ \\
\hline G2/N2/S2 & $\begin{array}{l}6 \text { to } 20 \text { or fewer occurrences or with many individuals in fewer locations. May be } \\
\text { especially vulnerable to extirpation because of some factor of its biology. }\end{array}$ \\
\hline G3/N3/S3 & $\begin{array}{l}21 \text { to } 100 \text { occurrences, may be rare and local throughout its range, or in a restricted } \\
\text { range (may be abundant in some locations). May be susceptible to extirpation } \\
\text { because of large-scale disturbances. }\end{array}$ \\
\hline G4/N4/S4 & Typically $>100$ occurrences. Apparently secure. \\
\hline G5/N5/S5 & Typically $>100$ occurrences. Demonstrably secure. \\
\hline GX/NX/SX & Believed to be extinct or extirpated, historical records only. \\
\hline GH/NH/SH & Historically known, may be relocated in the future. \\
\hline GNR/NNR/SNR & Unranked-conservation status not yet assessed. \\
\hline
\end{tabular}

E. United States Endangered Species Act (after National Research Council 1995)

\begin{tabular}{|l|l|}
\hline Endangered & $\begin{array}{l}\text { Any species which is in danger of extinction throughout all or a significant portion of } \\
\text { its range. }\end{array}$ \\
\hline Threatened & $\begin{array}{l}\text { Any species which is likely to become an endangered species within the foreseeable } \\
\text { future throughout all or a significant portion of its range. }\end{array}$ \\
\hline
\end{tabular}




\begin{tabular}{|c|c|c|c|c|c|}
\hline 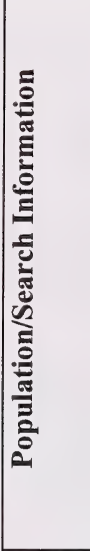 & 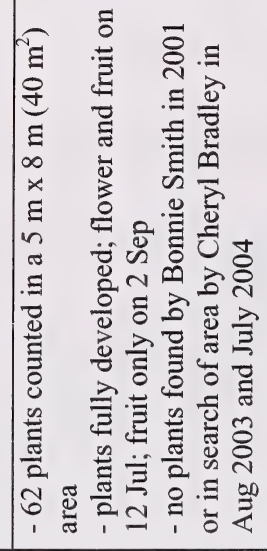 & 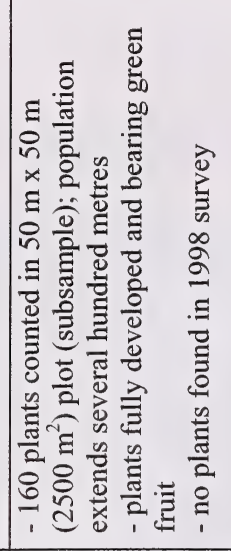 & 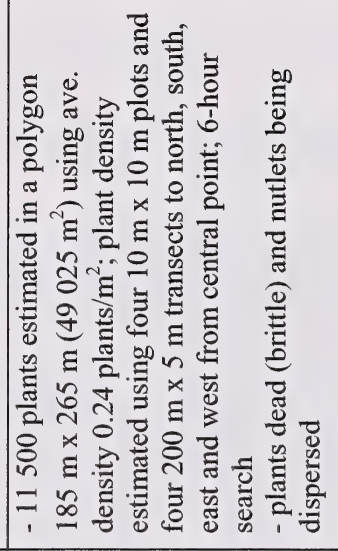 & 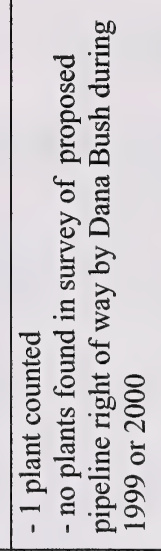 & 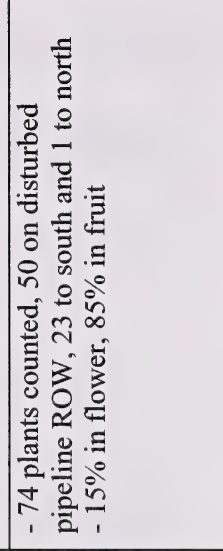 \\
\hline 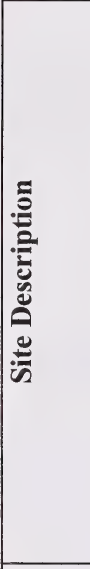 & 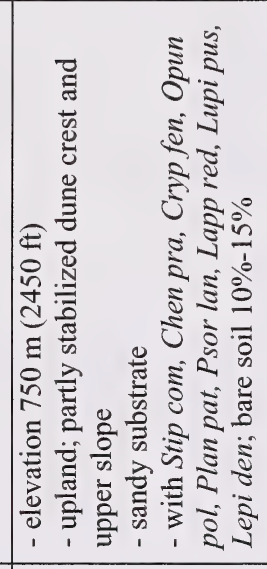 & 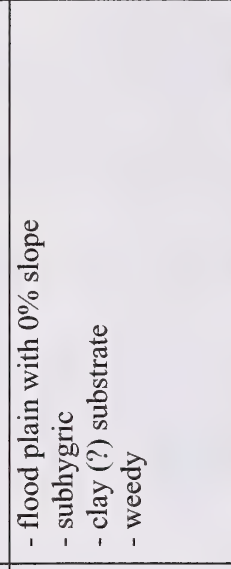 & 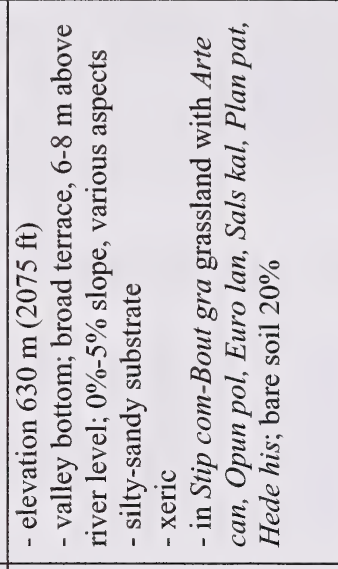 & 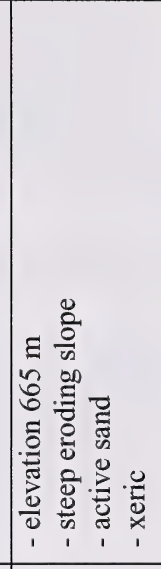 & 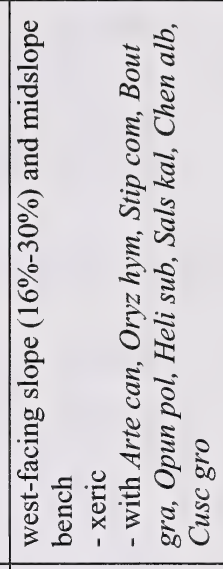 \\
\hline 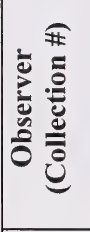 & 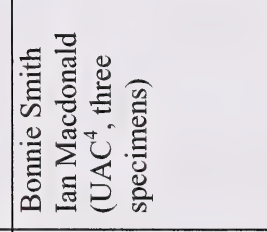 & 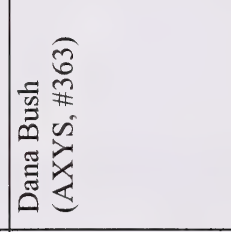 & 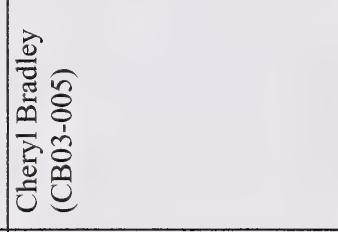 & 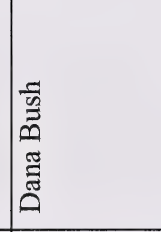 & 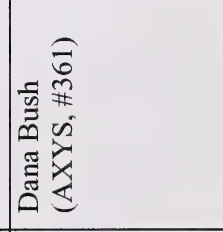 \\
\hline 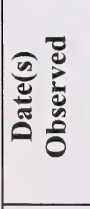 & 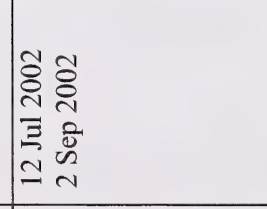 & 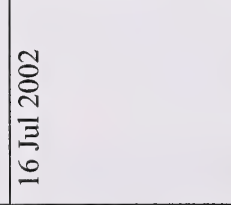 & 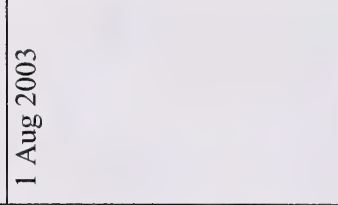 & $\begin{array}{l}\infty \\
\vdots \\
\vdots \\
\Xi \\
\\
m\end{array}$ & 总 \\
\hline 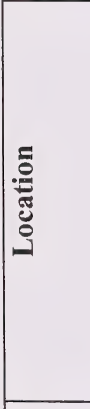 & 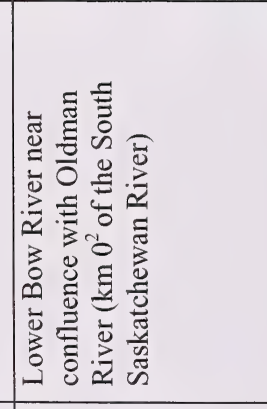 & 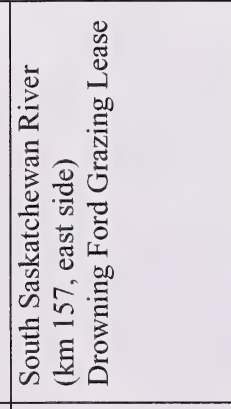 & 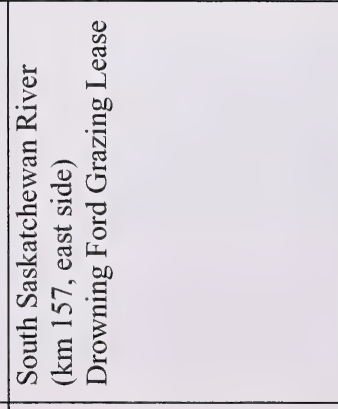 & 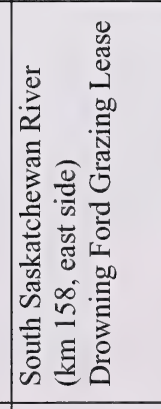 & 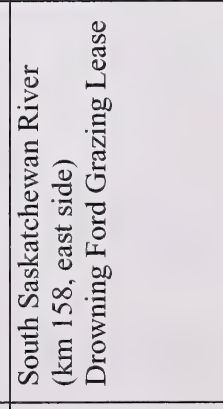 \\
\hline 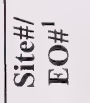 & 출 & 离号 & 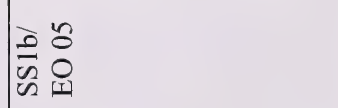 & 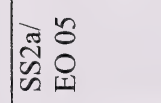 & 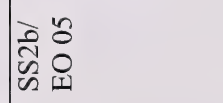 \\
\hline
\end{tabular}




\begin{tabular}{|c|c|c|c|}
\hline 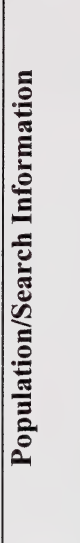 & 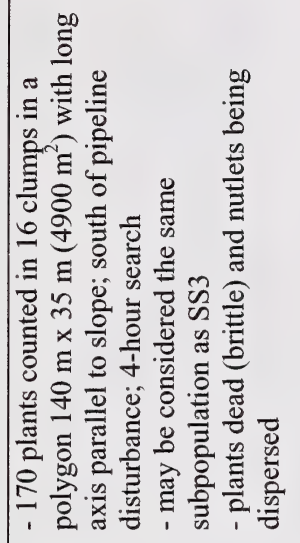 & 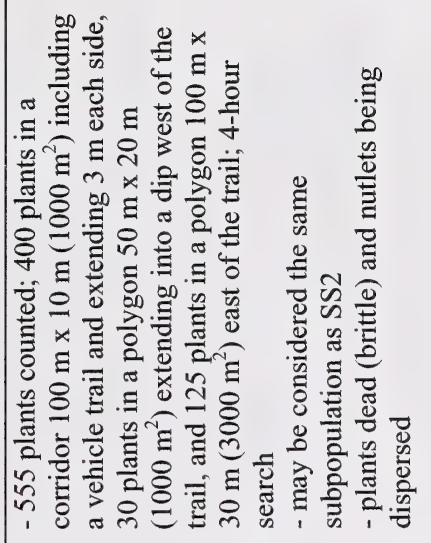 & 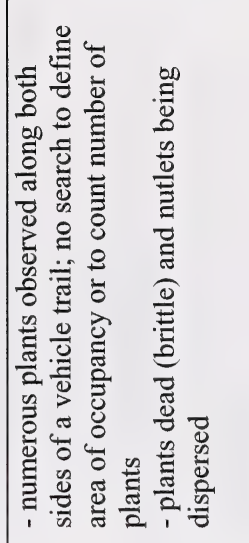 \\
\hline 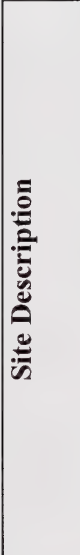 & 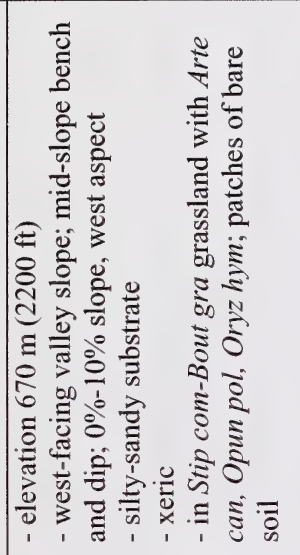 & 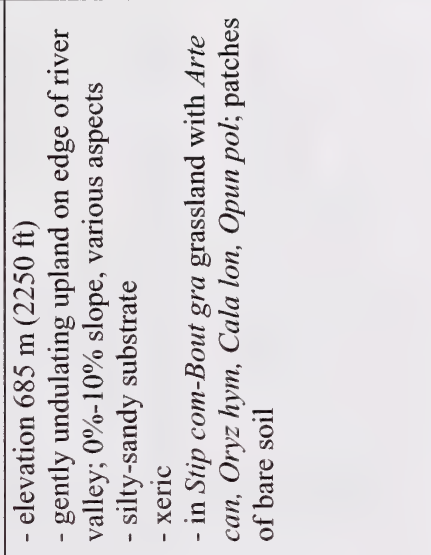 & 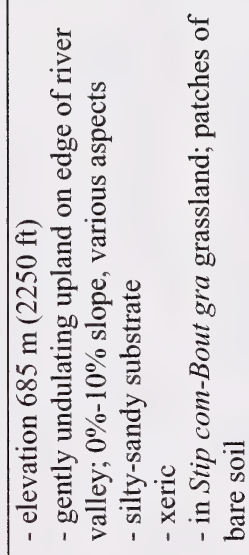 \\
\hline 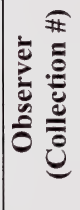 & 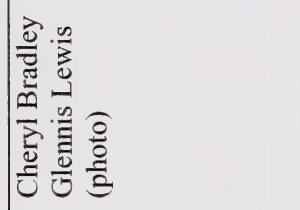 & 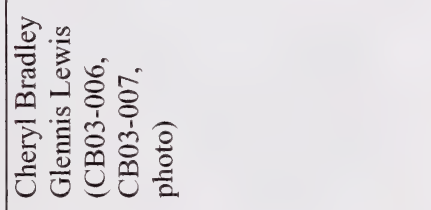 & 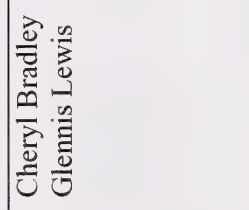 \\
\hline 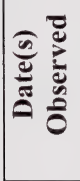 & 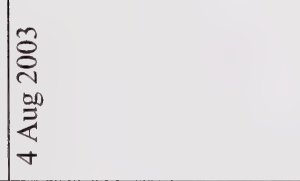 & 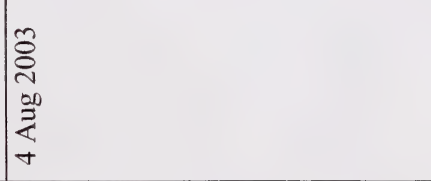 & 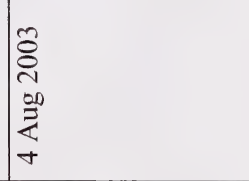 \\
\hline 吾 & 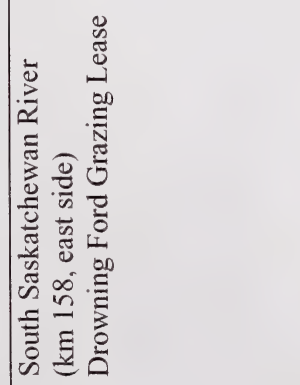 & 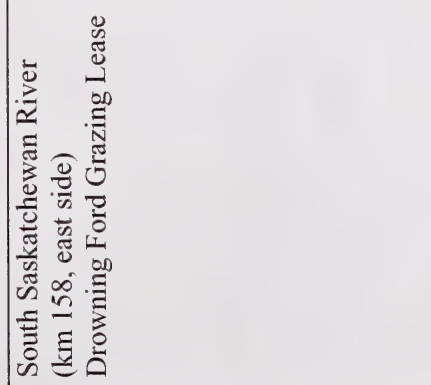 & 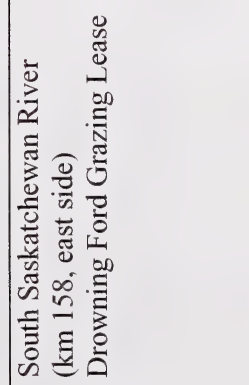 \\
\hline 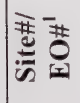 & 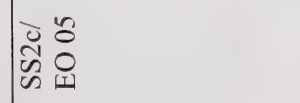 & 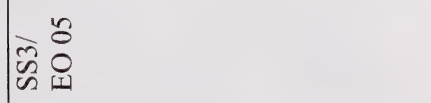 & 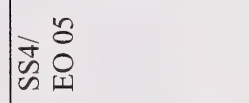 \\
\hline
\end{tabular}




\begin{tabular}{|c|c|c|c|c|}
\hline 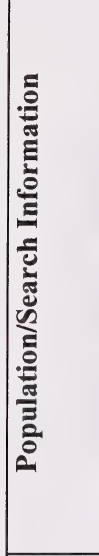 & 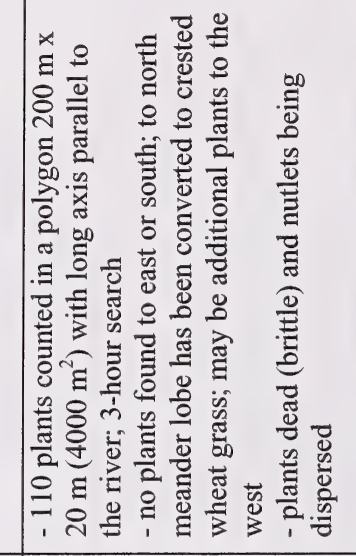 & 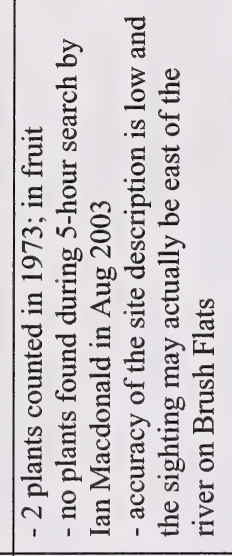 & 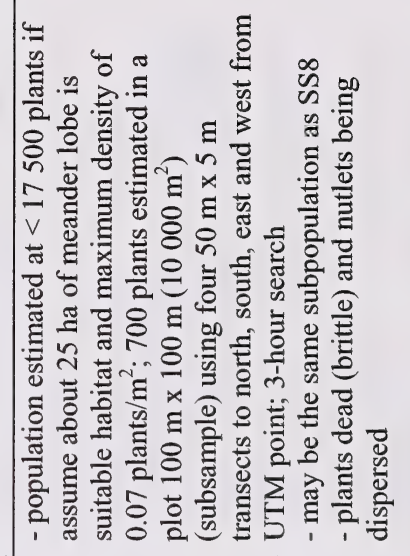 & 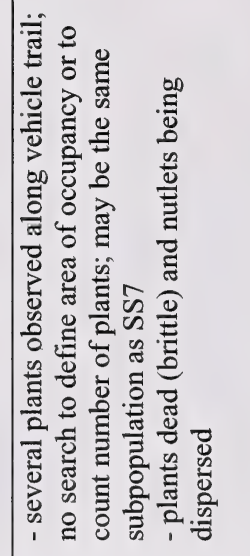 \\
\hline 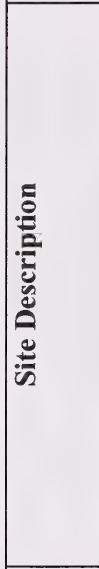 & 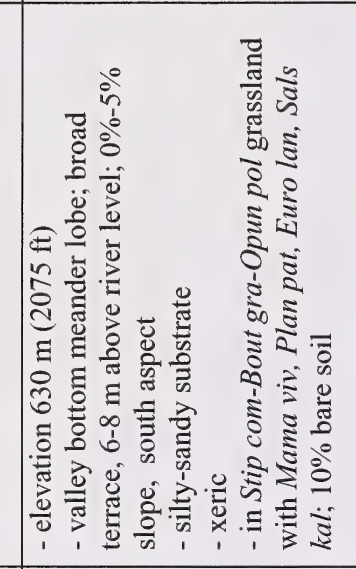 & & 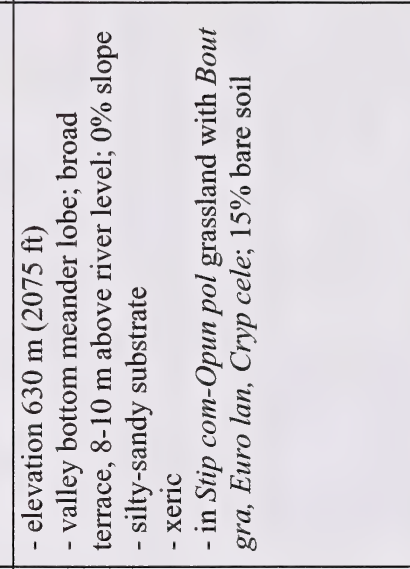 & 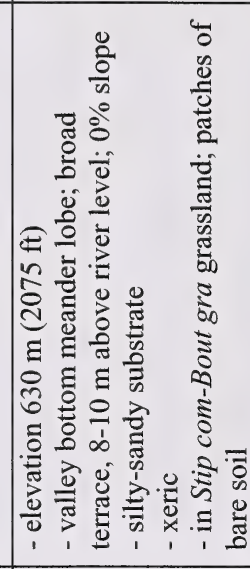 \\
\hline 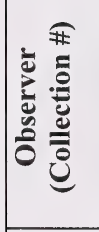 & 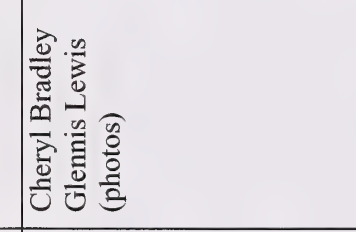 & 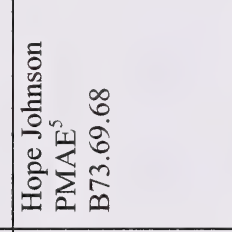 & 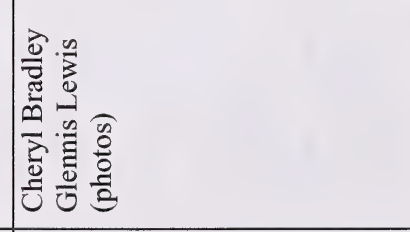 & 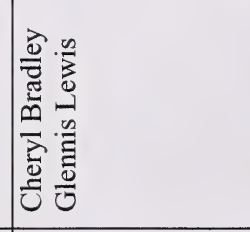 \\
\hline 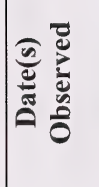 & 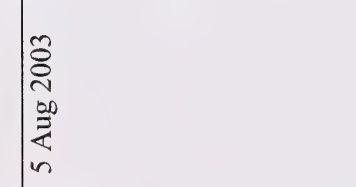 & 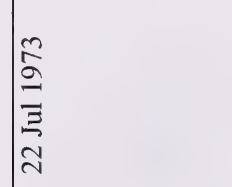 & 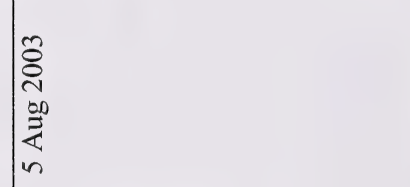 & 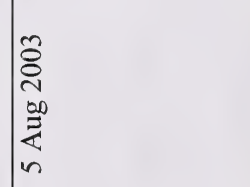 \\
\hline 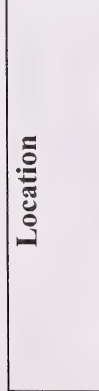 & 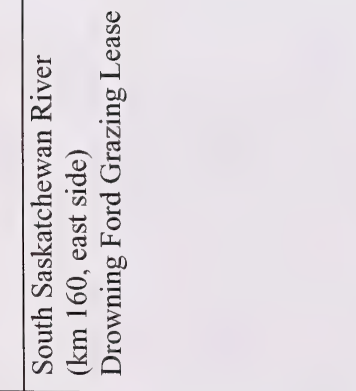 & 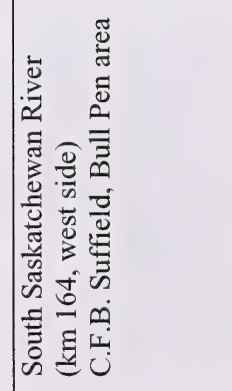 & 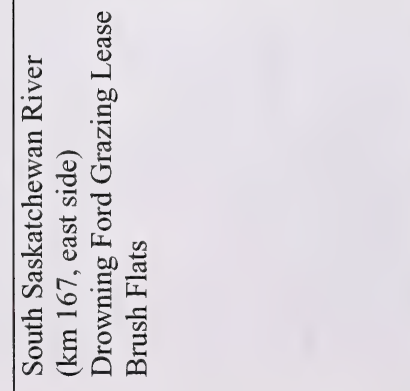 & 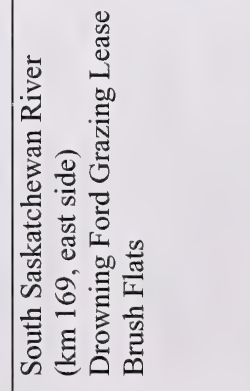 \\
\hline 5 & 愍。 & 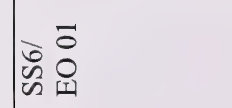 & 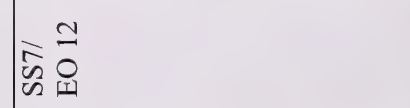 & 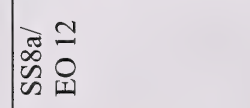 \\
\hline
\end{tabular}




\begin{tabular}{|c|c|c|c|}
\hline 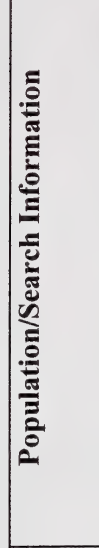 & 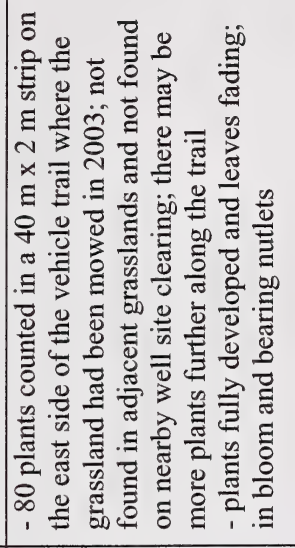 & 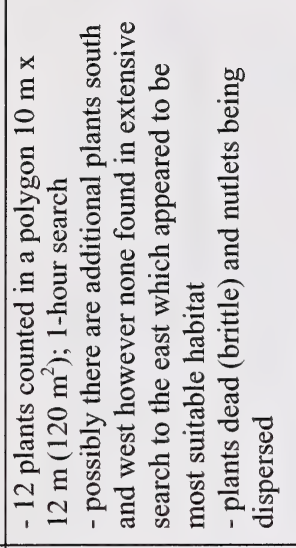 & 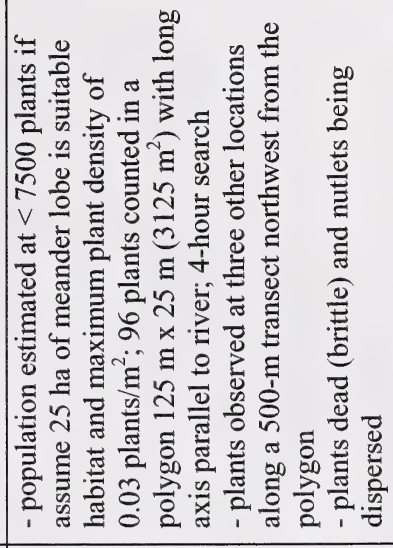 \\
\hline 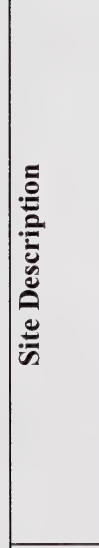 & 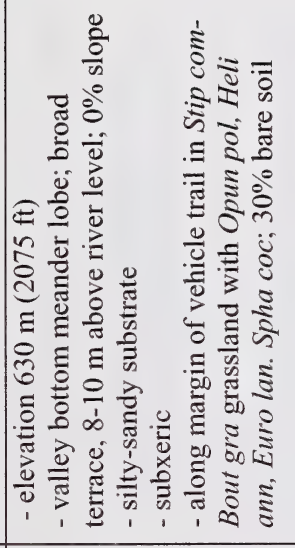 & 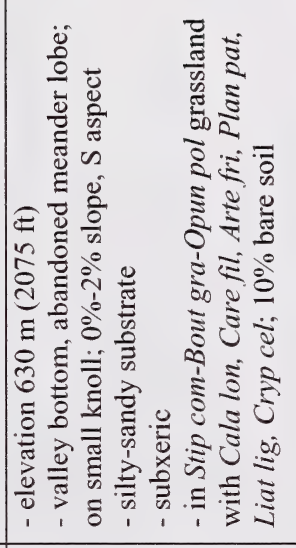 & 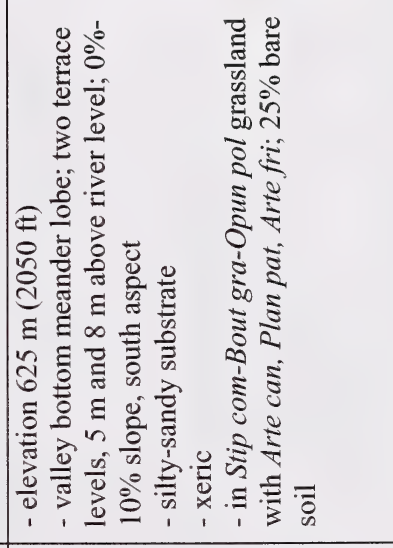 \\
\hline 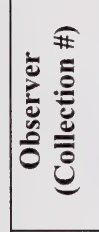 & 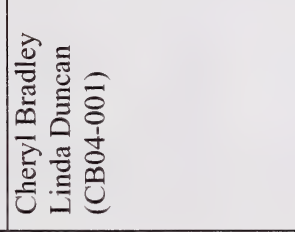 & 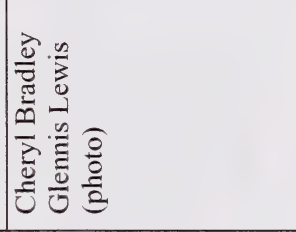 & 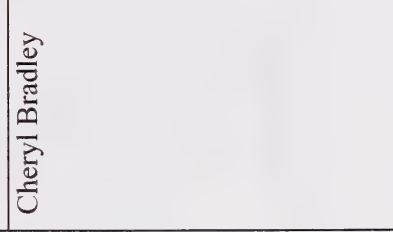 \\
\hline 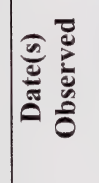 & 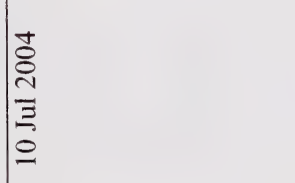 & 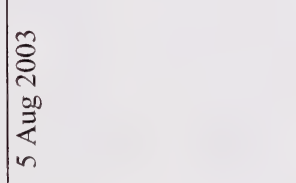 & 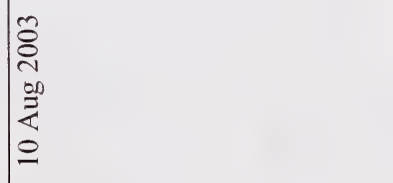 \\
\hline 选 & 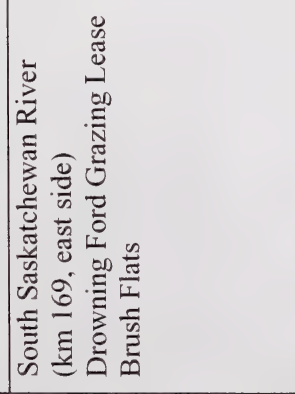 & 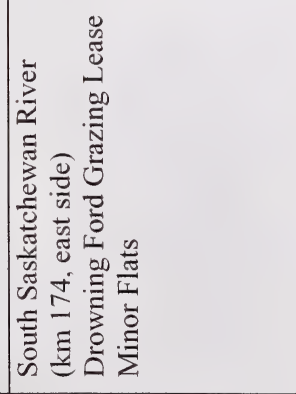 & 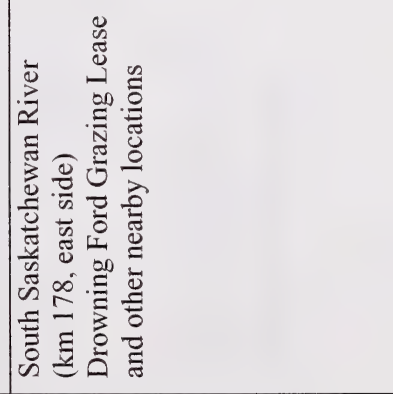 \\
\hline 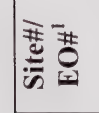 & 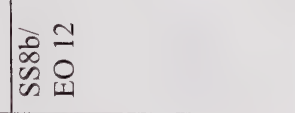 & 方 & $\begin{array}{l}\text { 음 } \\
\text { so } \\
\omega^{2}\end{array}$ \\
\hline
\end{tabular}




\begin{tabular}{|c|c|c|c|c|}
\hline & 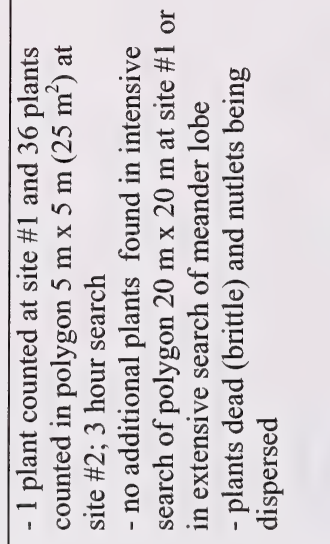 & 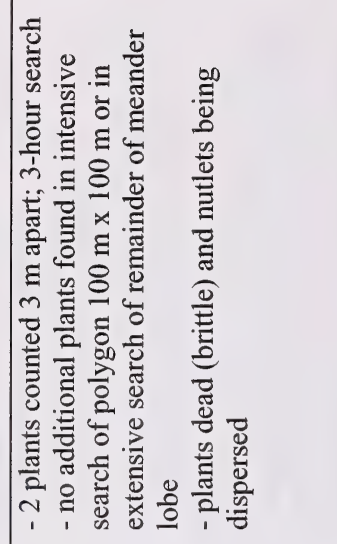 & 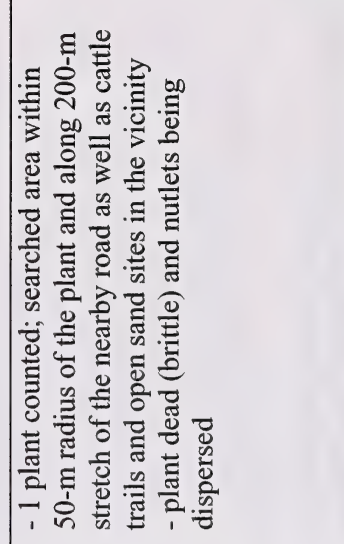 & 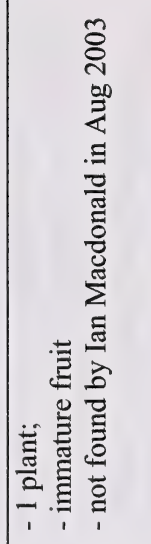 \\
\hline 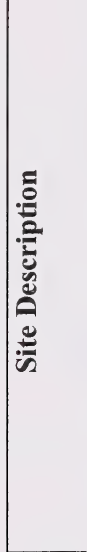 & 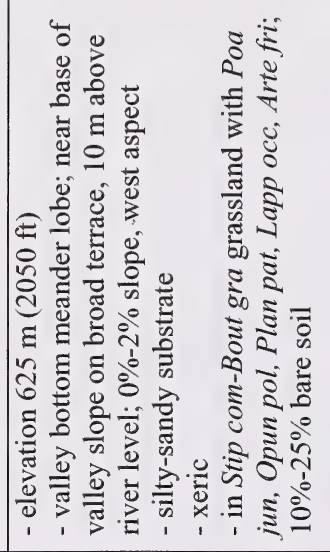 & 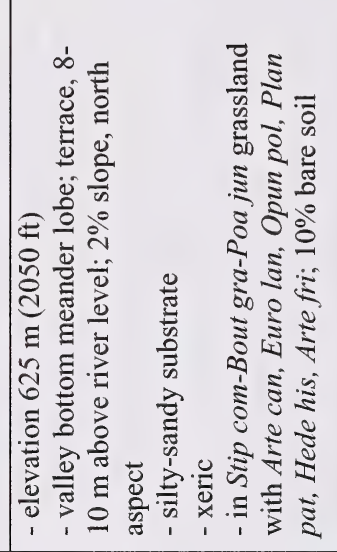 & 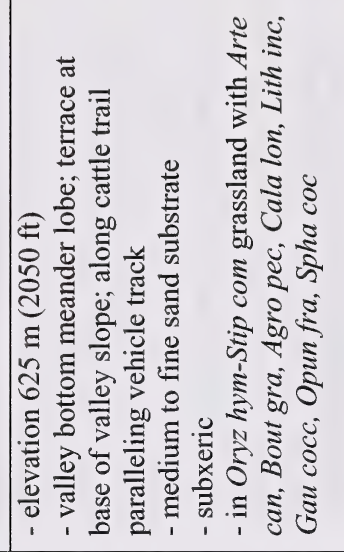 & 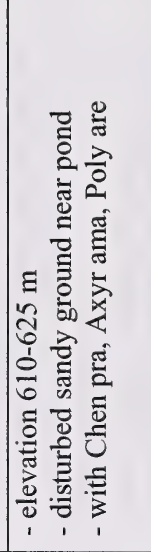 \\
\hline 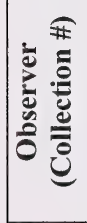 & 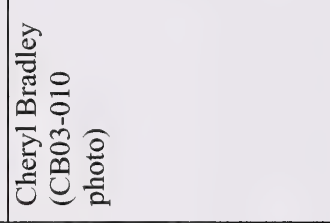 & 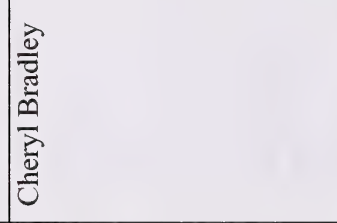 & 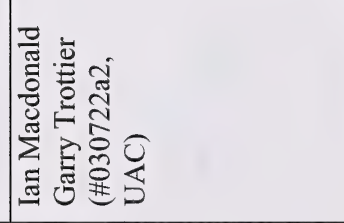 & 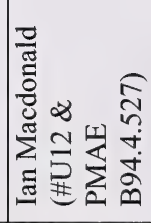 \\
\hline 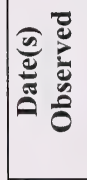 & 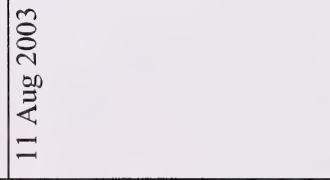 & 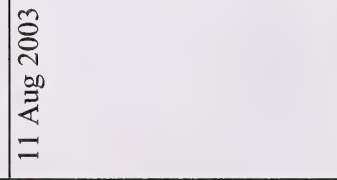 & 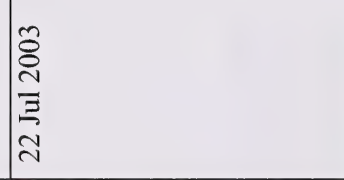 & 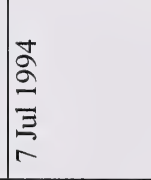 \\
\hline لِّ & 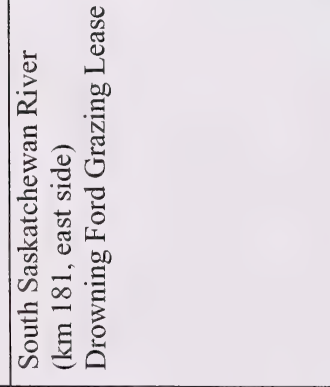 & 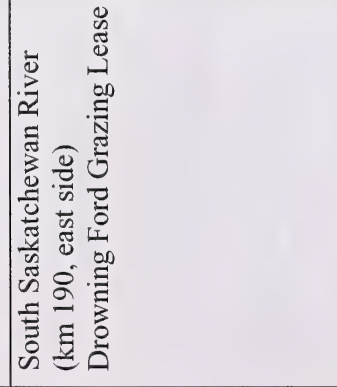 & 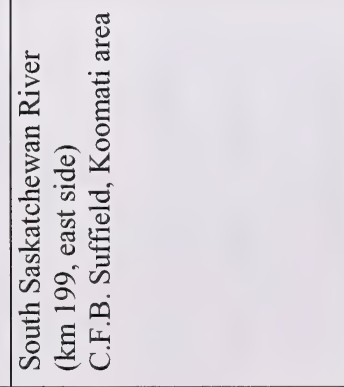 & 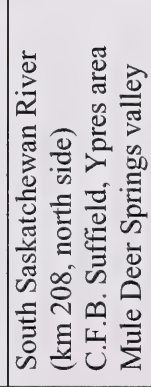 \\
\hline 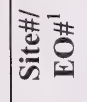 & 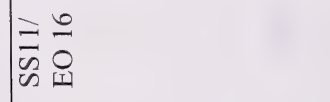 & 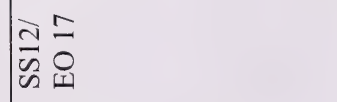 & 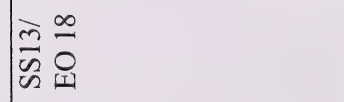 & 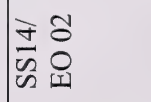 \\
\hline
\end{tabular}




\begin{tabular}{|c|c|c|}
\hline 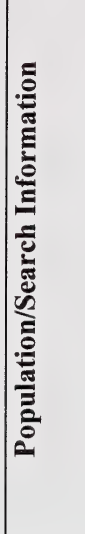 & 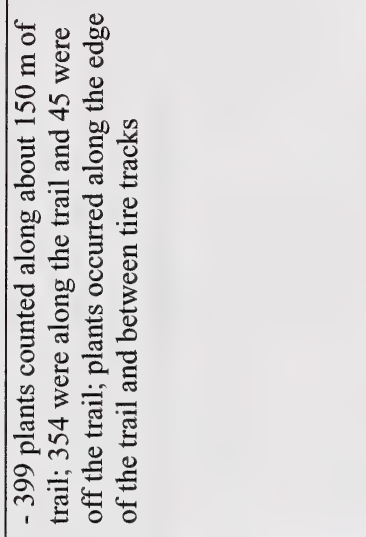 & 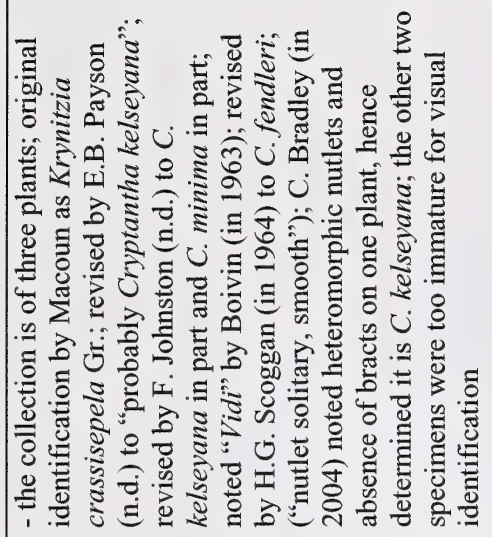 \\
\hline 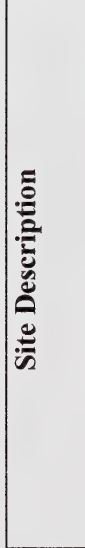 & 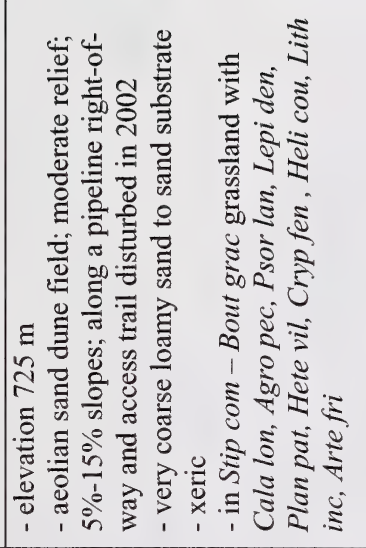 & 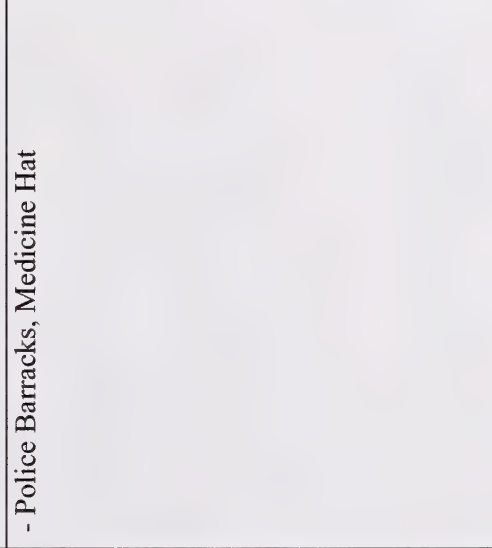 \\
\hline 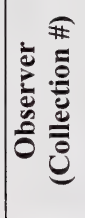 & 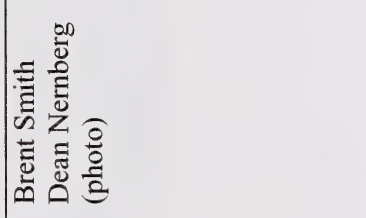 & 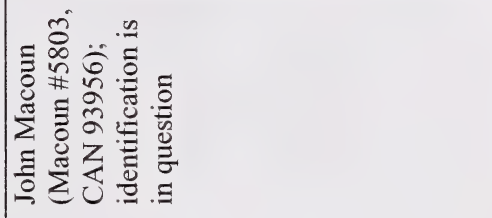 \\
\hline 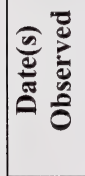 & 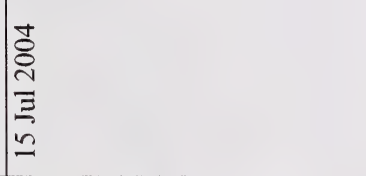 & 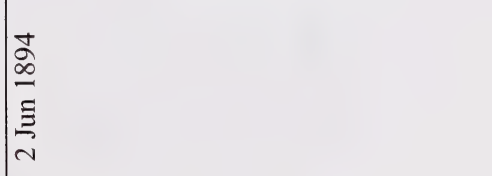 \\
\hline 远 & 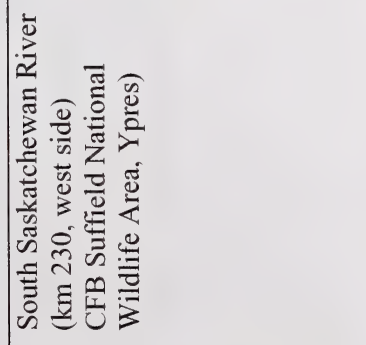 & 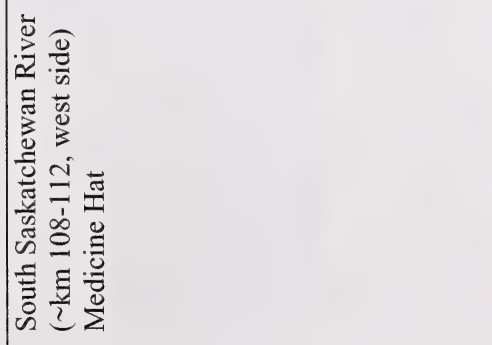 \\
\hline 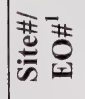 & 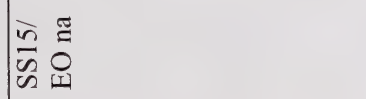 & 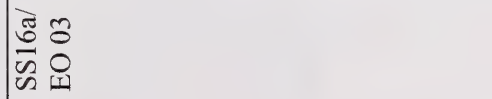 \\
\hline
\end{tabular}




\begin{tabular}{|c|c|c|}
\hline 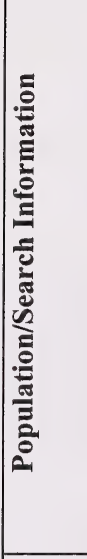 & 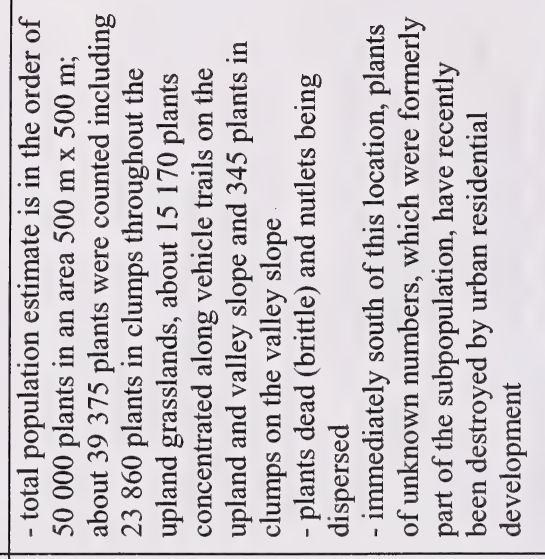 & 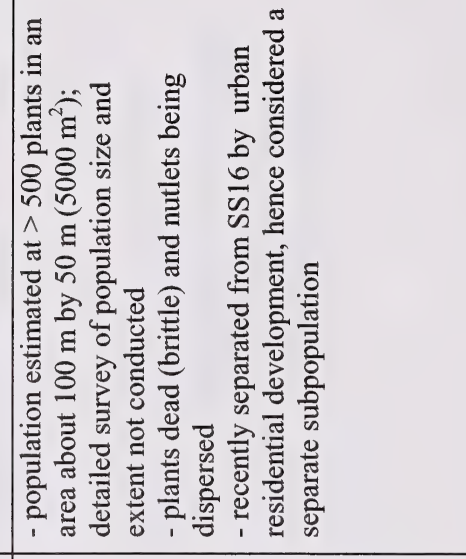 \\
\hline 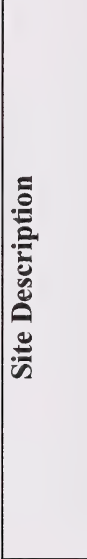 & 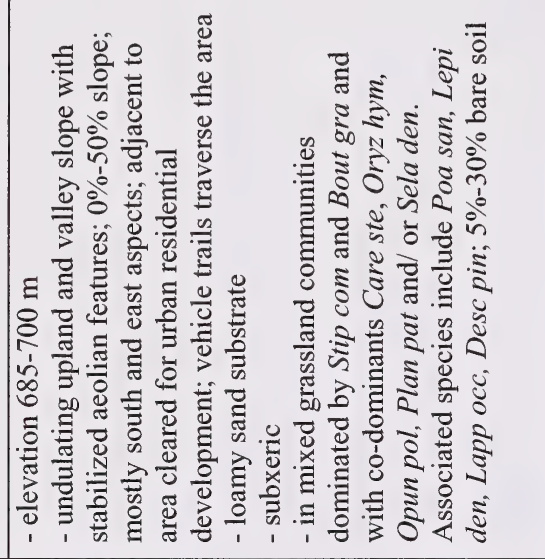 & 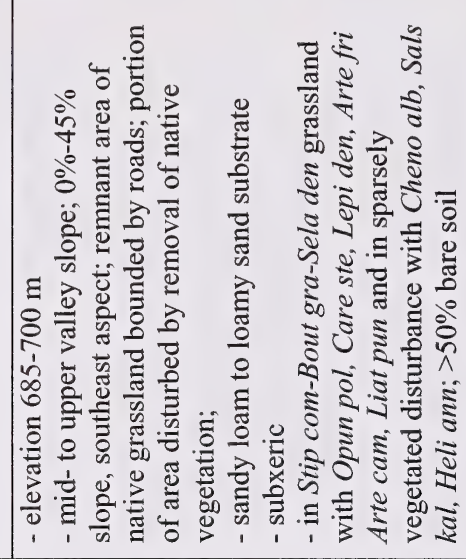 \\
\hline 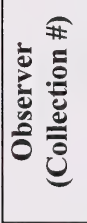 & 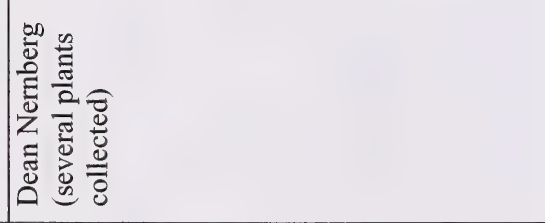 & 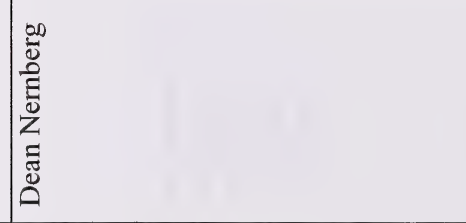 \\
\hline 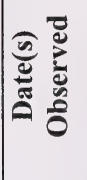 & 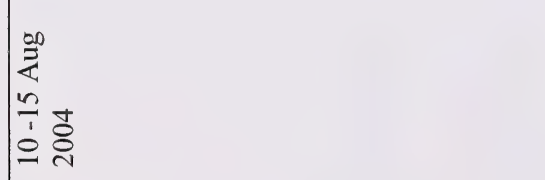 & 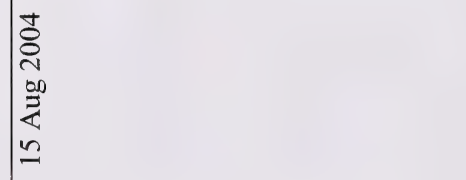 \\
\hline $\mid$ & 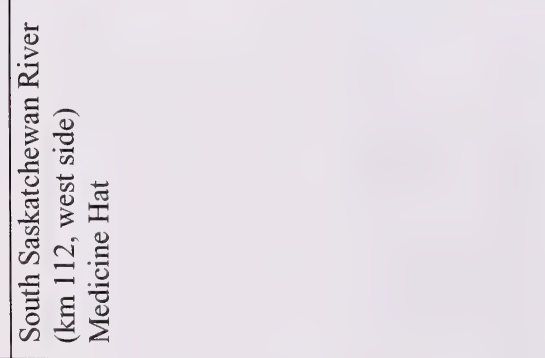 & 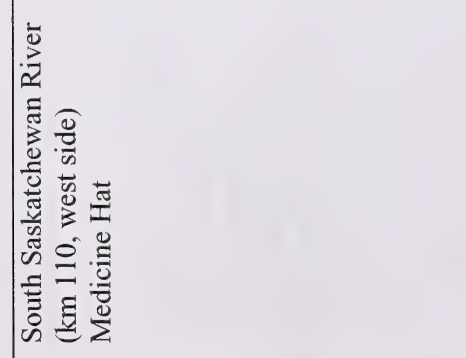 \\
\hline 琶美 & 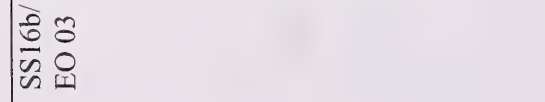 & 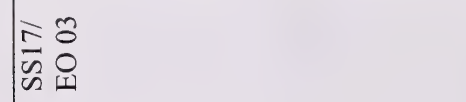 \\
\hline
\end{tabular}

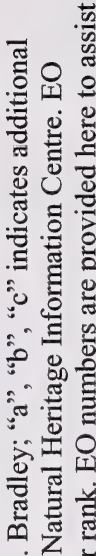

ن

흐류

<

毛综

\& $=2$

ปै

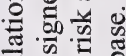

政

는

空

政

-

政

एँ

\&

要娄

응 응

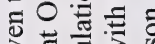

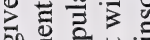

ह

可

政

5.

on 플

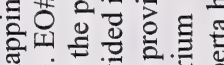
छํ.

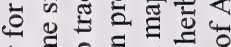

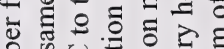
है

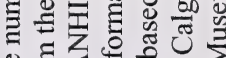

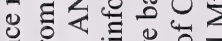
둥 눈 는

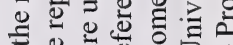
\#

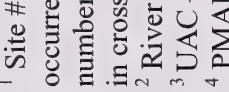




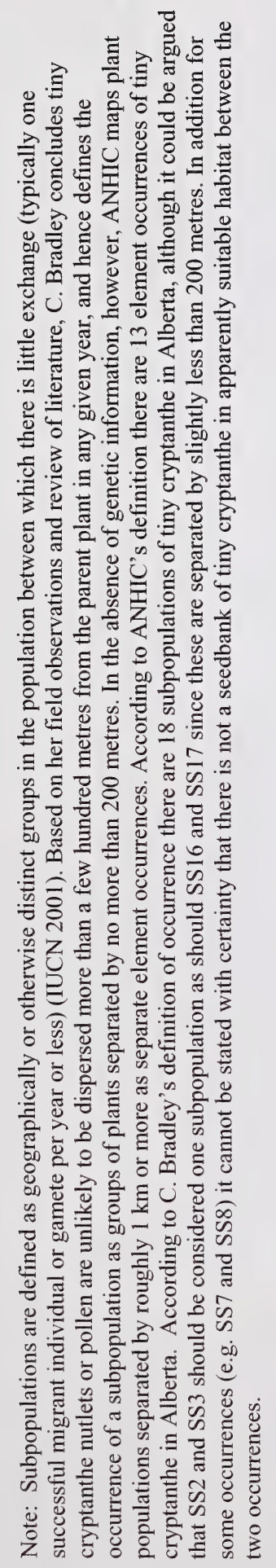




\begin{tabular}{|c|c|c|c|c|}
\hline 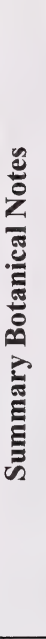 & 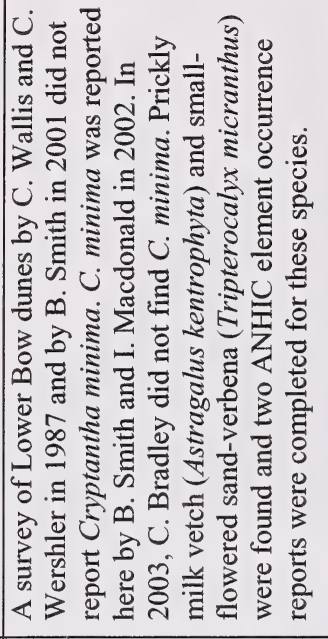 & 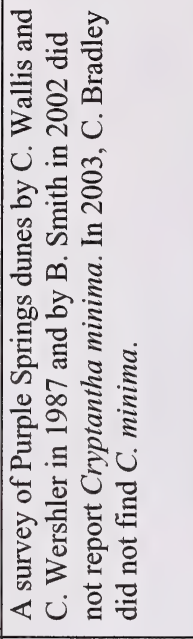 & 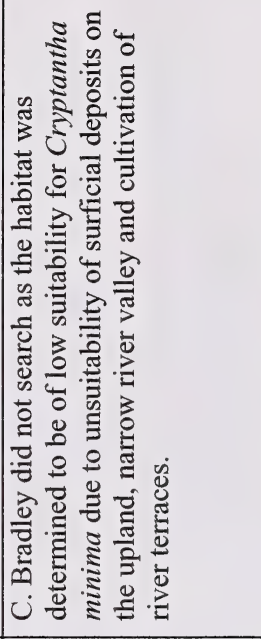 & 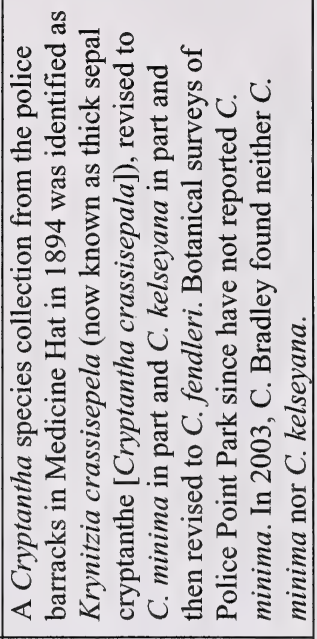 \\
\hline & 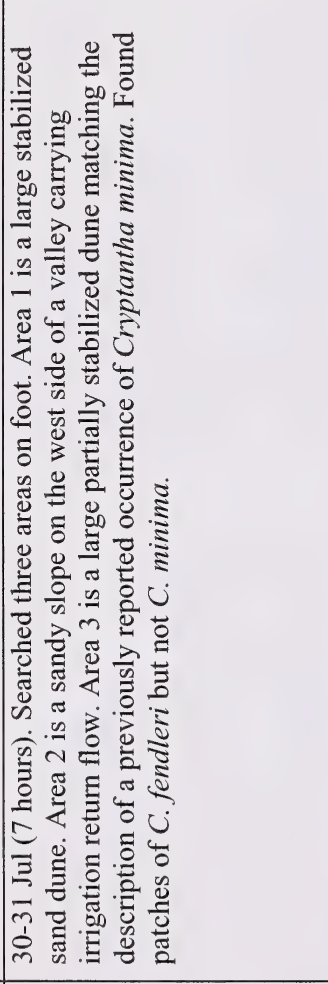 & 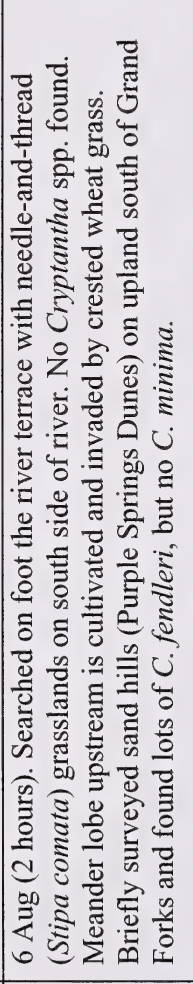 & 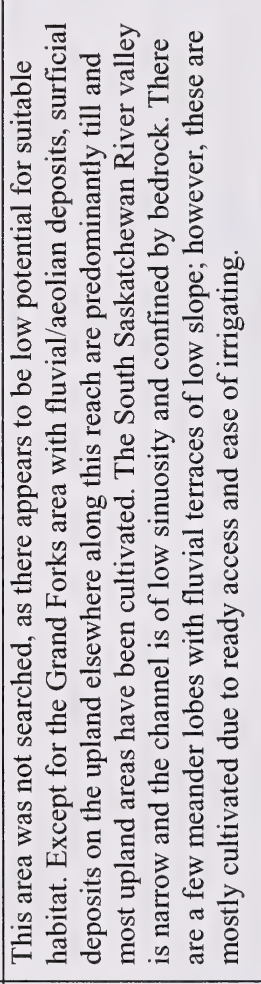 & 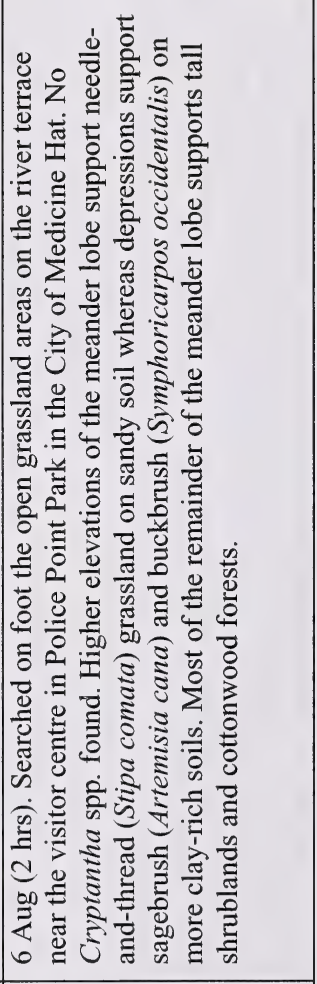 \\
\hline & 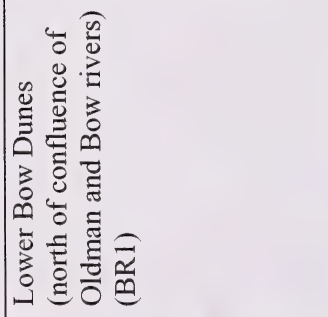 & 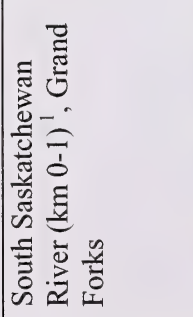 & 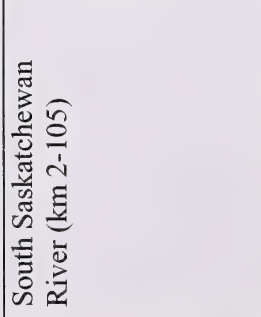 & 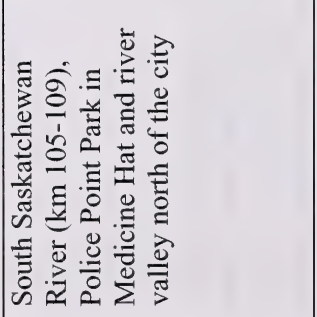 \\
\hline
\end{tabular}




\begin{tabular}{|c|c|c|c|}
\hline 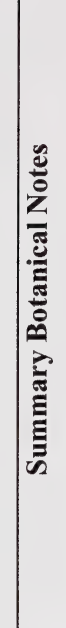 & 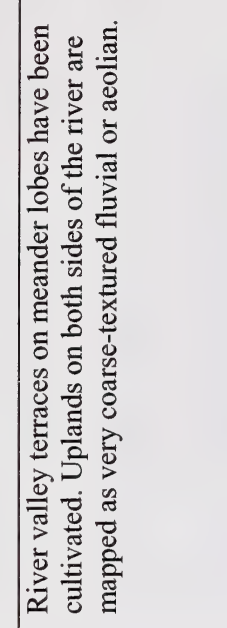 & 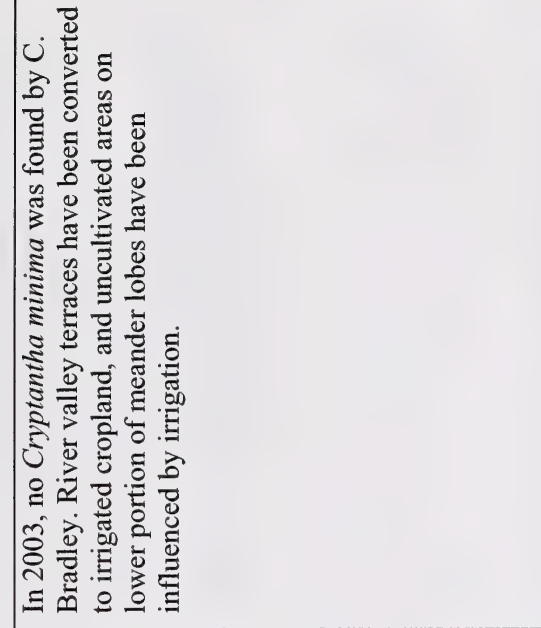 & 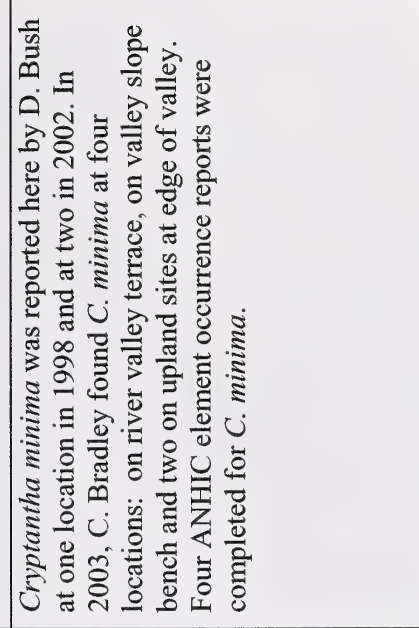 \\
\hline & 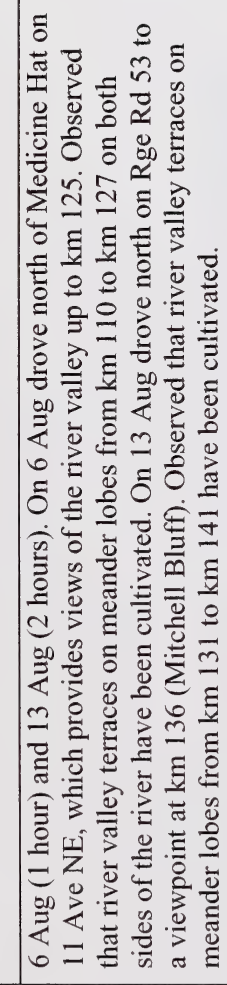 & 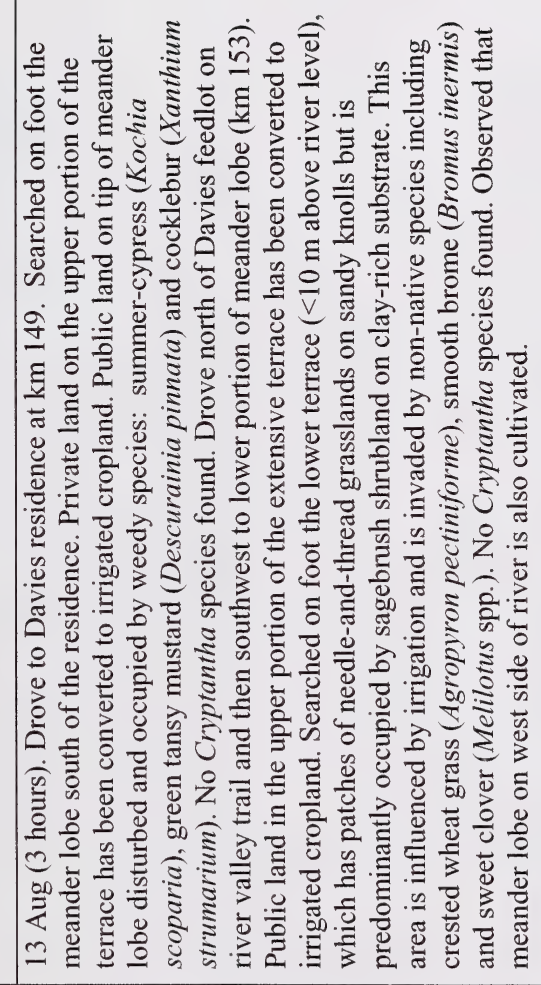 & 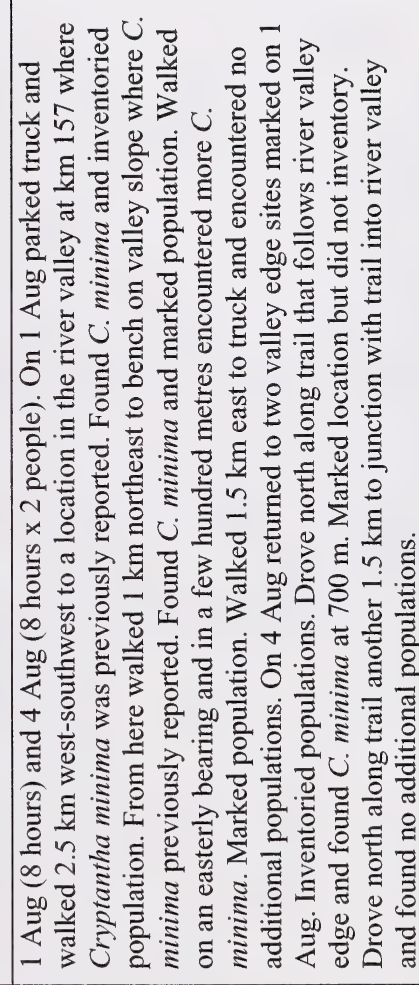 \\
\hline & 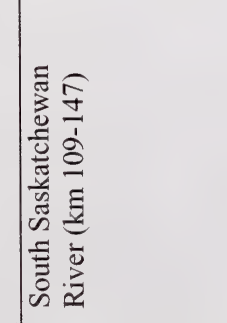 & 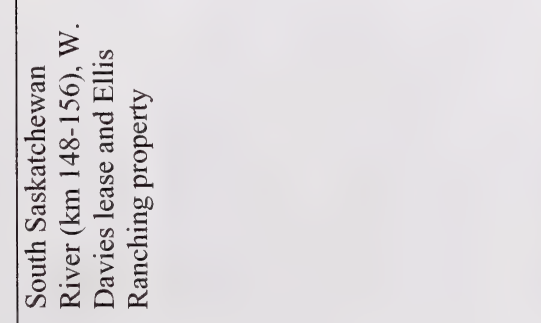 & 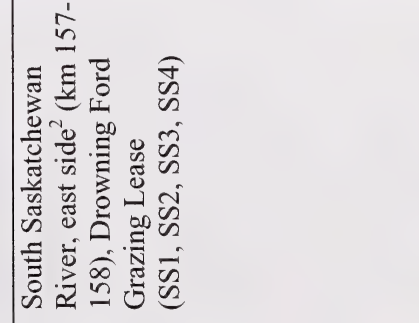 \\
\hline
\end{tabular}




\begin{tabular}{|c|c|c|c|}
\hline & 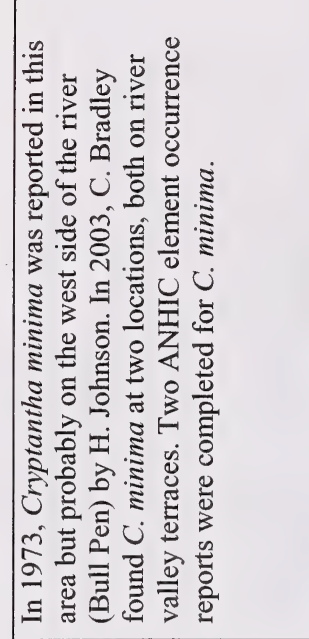 & 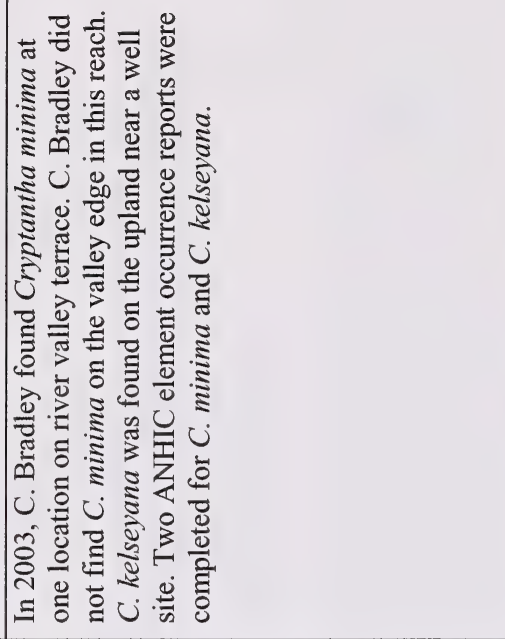 & 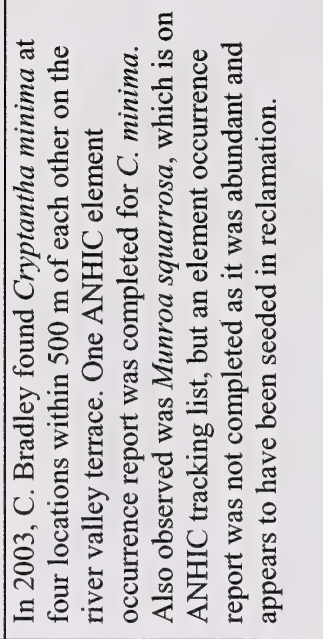 \\
\hline & 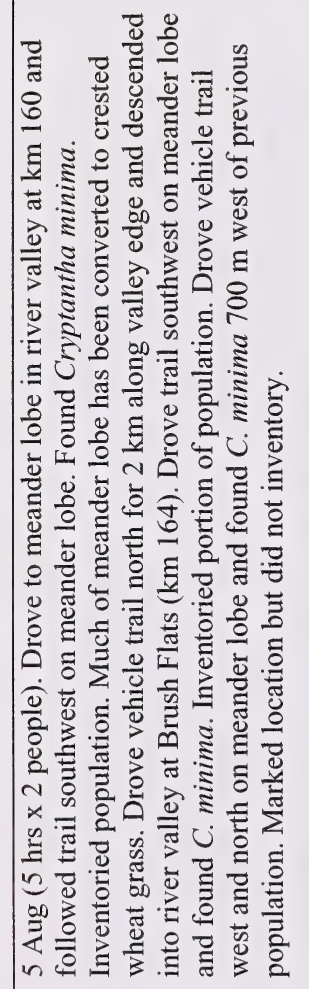 & 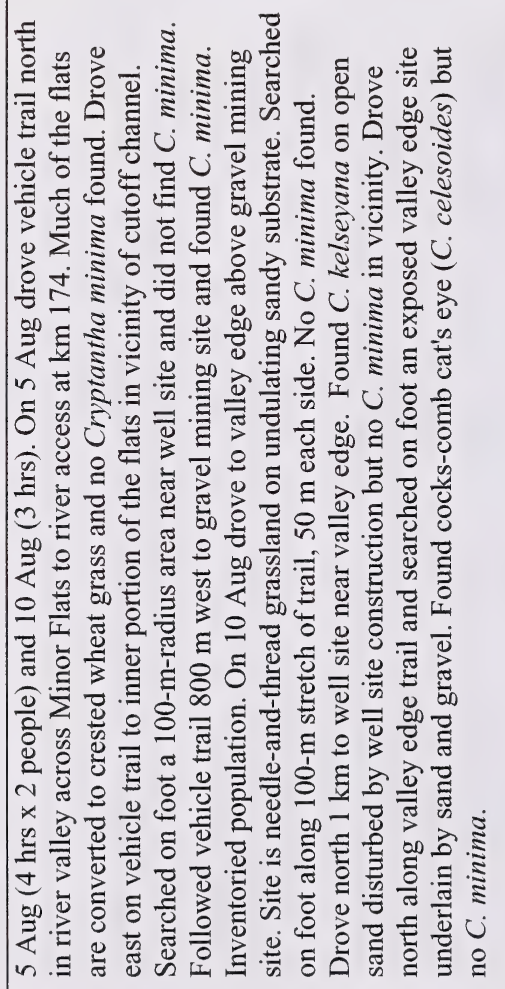 & 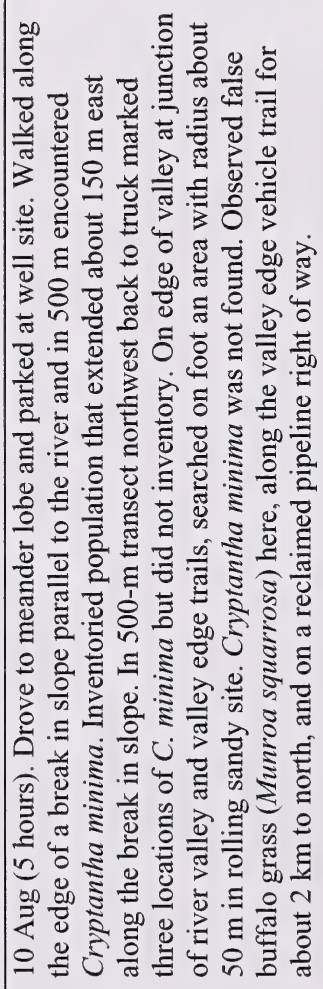 \\
\hline & 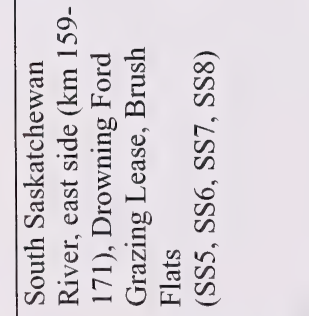 & 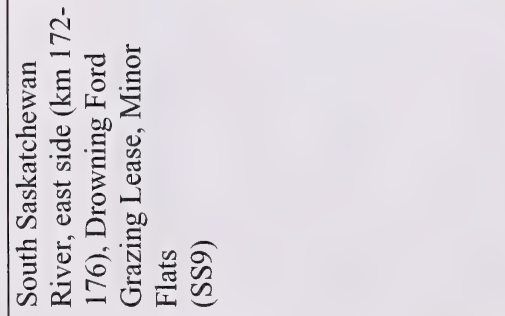 & 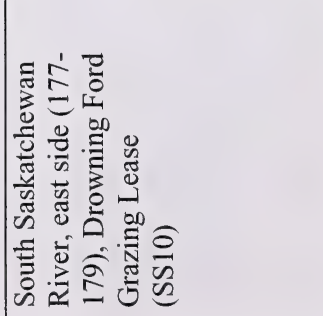 \\
\hline
\end{tabular}




\begin{tabular}{|c|c|c|c|c|c|c|}
\hline & 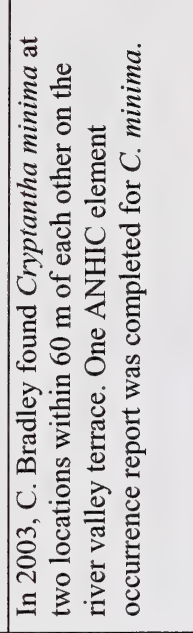 & 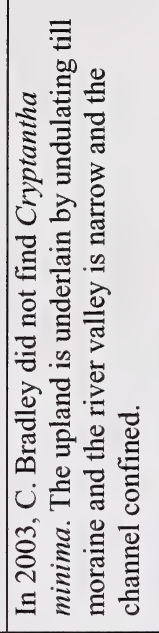 & 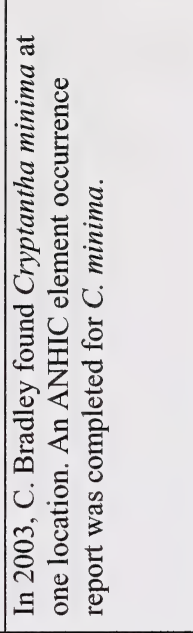 & 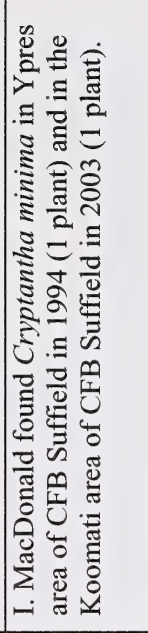 & 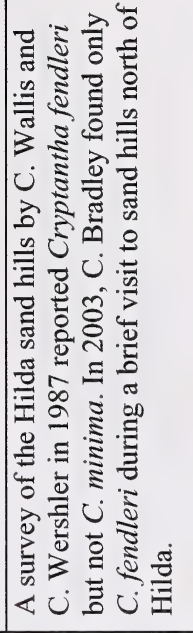 & 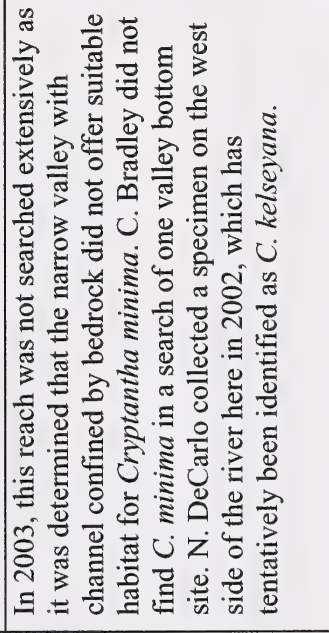 \\
\hline & 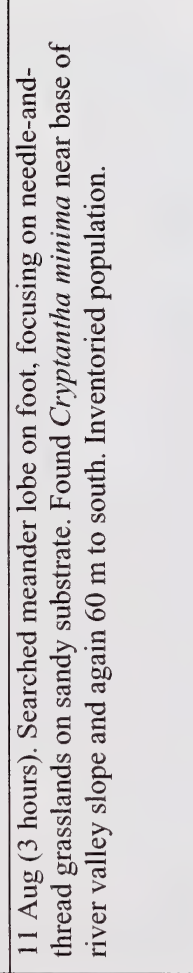 & 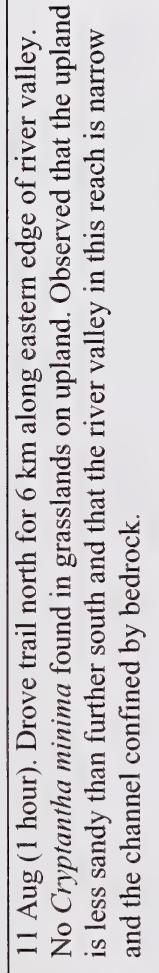 & 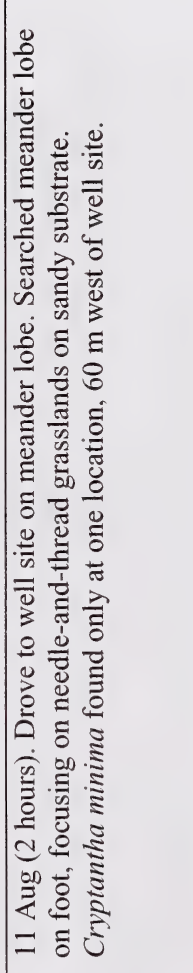 & 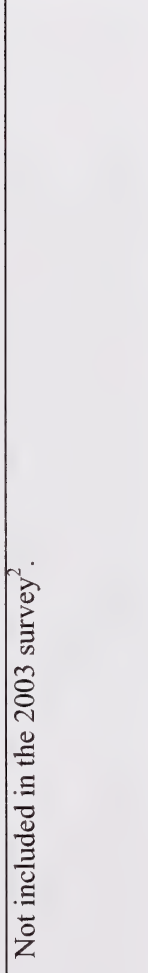 & 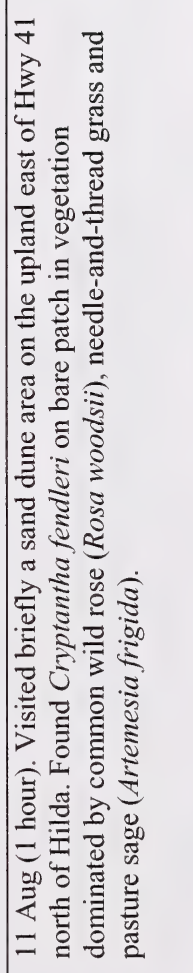 & 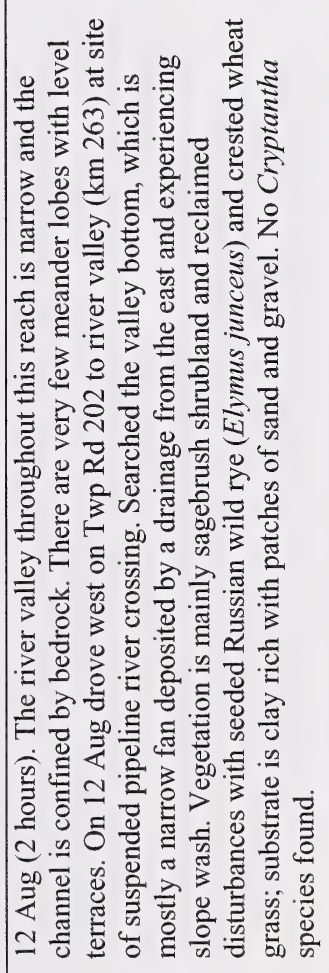 \\
\hline 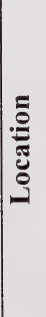 & 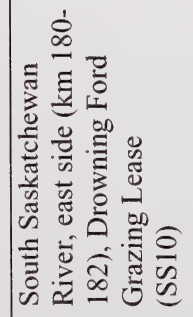 & 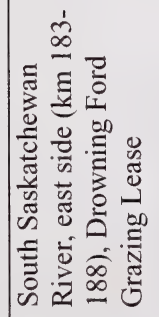 & 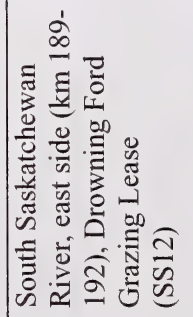 & 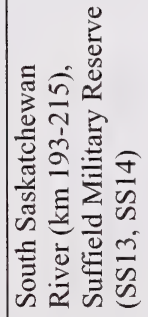 & 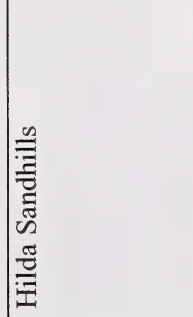 & 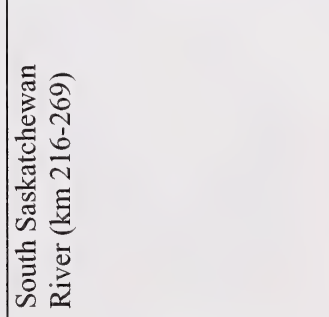 \\
\hline
\end{tabular}




\begin{tabular}{|c|c|c|c|c|}
\hline & 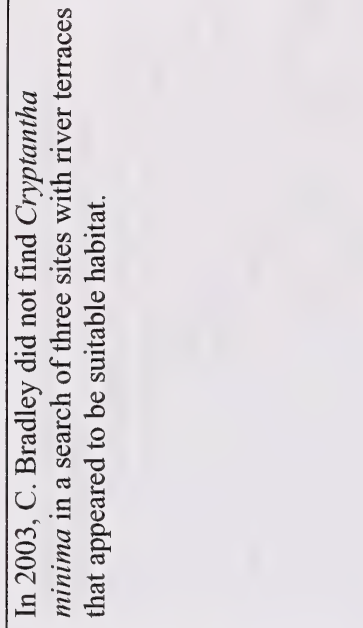 & 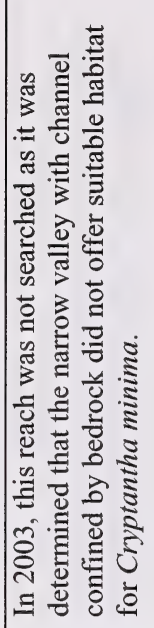 & 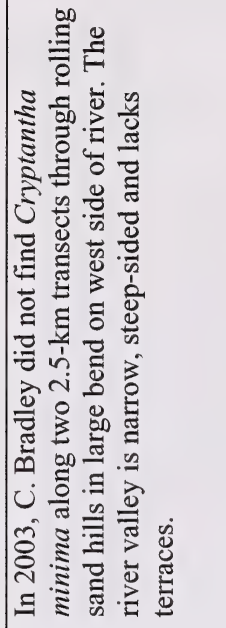 & 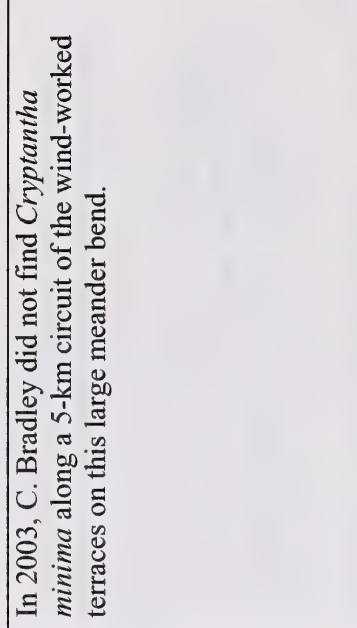 \\
\hline & 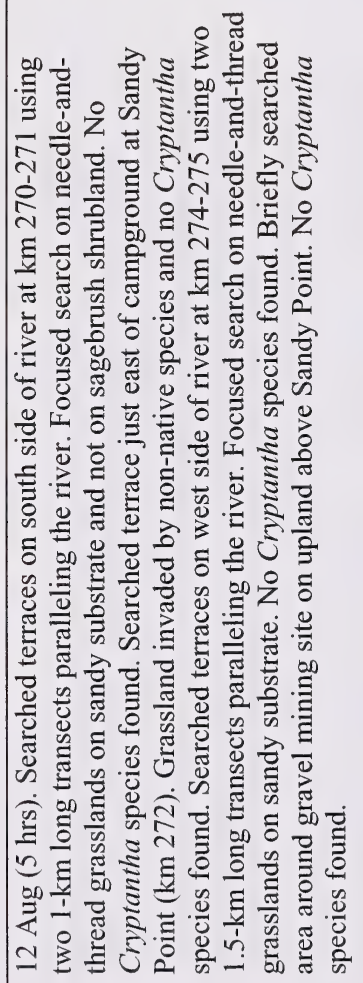 & 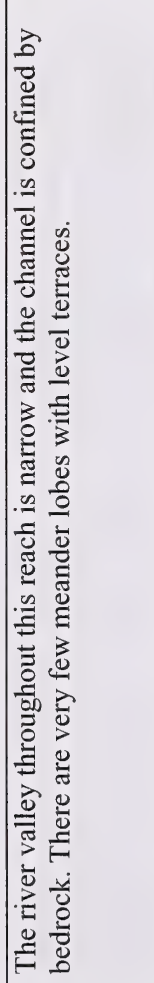 & 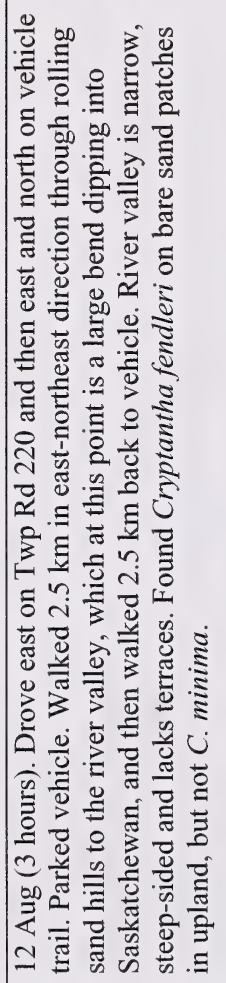 & 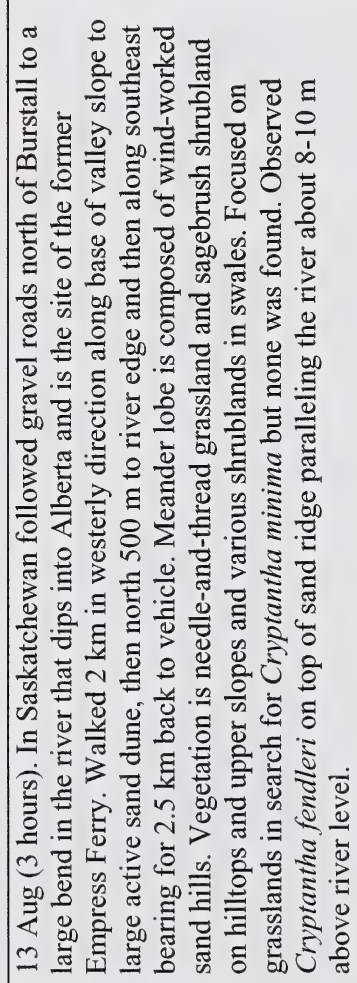 \\
\hline 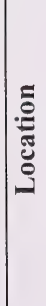 & 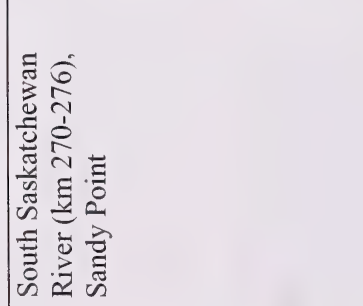 & 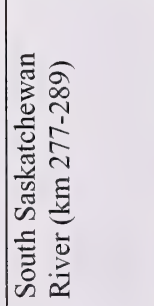 & 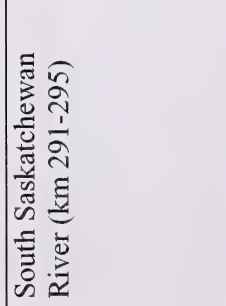 & 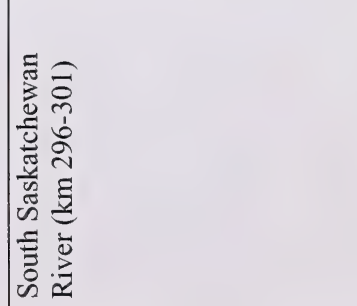 \\
\hline
\end{tabular}




\begin{tabular}{|c|c|c|c|}
\hline & 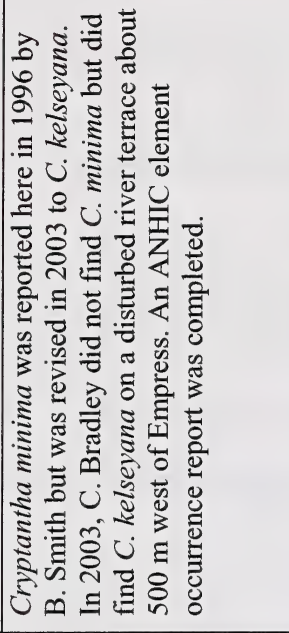 & 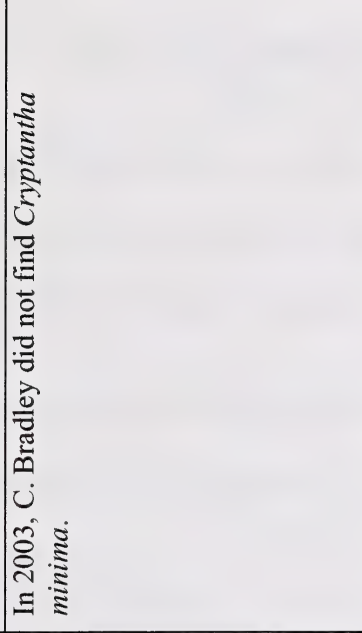 & 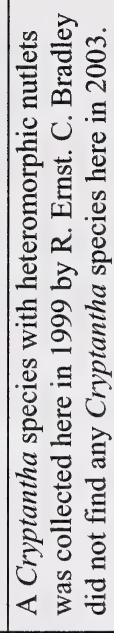 \\
\hline & 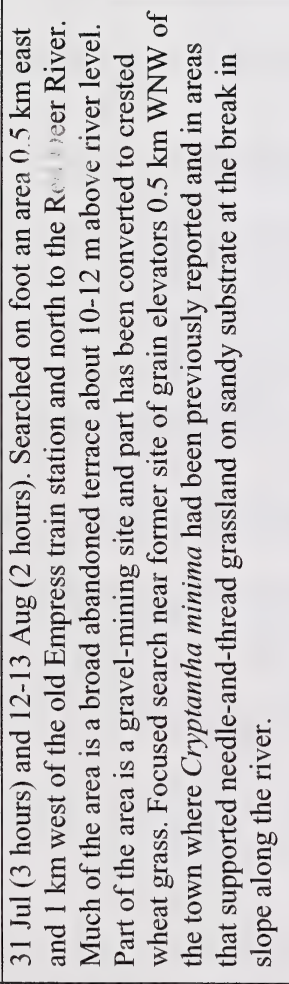 & 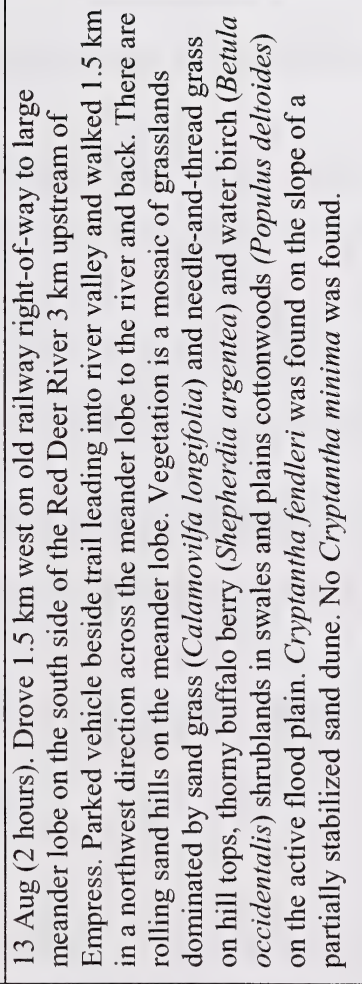 & 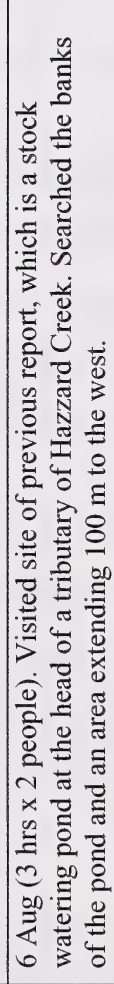 \\
\hline 赵 & 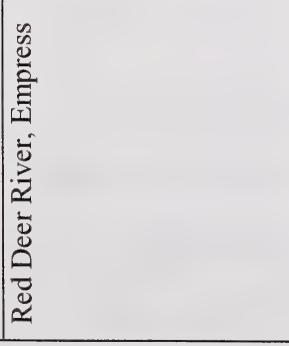 & 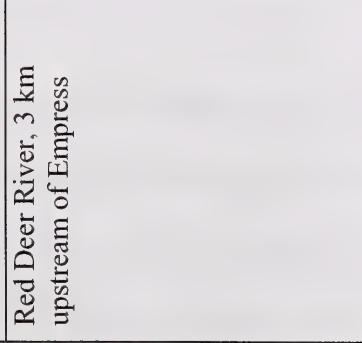 & 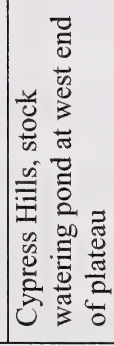 \\
\hline
\end{tabular}




\section{List of Titles in This Series \\ (as of September 2004)}

No. 1 Status of the Piping Plover (Charadrius melodus) in Alberta, by David R. C. Prescott. 19 pp. (1997)

No. 2 Status of the Wolverine (Gulo gulo) in Alberta, by Stephen Petersen. 17 pp. (1997)

No. 3 Status of the Northern Long-eared Bat (Myotis septentrionalis) in Alberta, by M. Carolina Caceres and M. J. Pybus. 19 pp. (1997)

No. 4 Status of the Ord's Kangaroo Rat (Dipodomys ordii) in Alberta, by David L. Gummer. 16 pp. (1997)

No. 5 Status of the Eastern Short-horned Lizard (Phrynosoma douglassii brevirostre) in Alberta, by Janice D. James, Anthony P. Russell and G. Lawrence Powell. 20 pp. (1997)

No. 5 Update 2004. Status of the Short-horned Lizard (Phrynosoma hernandesi) in Alberta. Alberta Sustainable Resource Development. 27 pp. (2004)

No. 6 Status of the Prairie Rattlesnake (Crotalus viridis viridis) in Alberta, by Sheri M. Watson and Anthony P. Russell. 26 pp. (1997)

No. 7 Status of the Swift Fox (Vulpes velox) in Alberta, by Susan E. Cotterill. 17 pp. (1997)

No. 8 Status of the Peregrine Falcon (Falco peregrinus anatum) in Alberta, by Petra Rowell and David P. Stepnisky. 23 pp. (1997)

No. 9 Status of the Northern Leopard Frog (Rana pipiens) in Alberta, by Greg Wagner. 46 pp. (1997)

No. 9 Update 2003. Status of the Northern Leopard Frog (Rana pipiens) in Alberta. Alberta Sustainable Resource Development. 61 pp. (2003)

No. 10 Status of the Sprague's Pipit (Anthus spragueii) in Alberta, by David R. C. Prescott. 14 pp. (1997)

No. 11 Status of the Burrowing Owl (Speotyto cunicularia hypugaea) in Alberta, by Troy I. Wellicome. 21 pp. (1997)

No. 12 Status of the Canadian Toad (Bufo hemiophrys) in Alberta, by Ian M. Hamilton, Joann L. Skilnick, Howard Troughton, Anthony P. Russell, and G. Lawrence Powell. 30 pp. (1998)

No. 13 Status of the Sage Grouse (Centrocercus urophasianus urophasianus) in Alberta, by Cameron L. Aldridge. 23 pp. (1998)

No. 14 Status of the Great Plains Toad (Bufo cognatus) in Alberta, by Janice D. James. 26 pp. (1998)

No. 15 Status of the Plains Hognose Snake (Heterodon nasicus nasicus) in Alberta, by Jonathan Wright and Andrew Didiuk. 26 pp. (1998)

No. 16 Status of the Long-billed Curlew (Numenius americanus) in Alberta, by Dorothy P. Hill. 20 pp. (1998)

No. 17 Status of the Columbia Spotted Frog (Rana luteiventris) in Alberta, by Janice D. James. 21 pp. (1998)

No. 18 Status of the Ferruginous Hawk (Buteo regalis) in Alberta, by Josef K. Schmutz. 18 pp. (1999)

No. 19 Status of the Red-tailed Chipmunk (Tamias ruficaudus) in Alberta, by Ron Bennett. 15 pp. (1999)

No. 20 Status of the Northern Pygmy Owl (Glaucidium gnoma californicum) in Alberta, by Kevin C. Hannah. 20 pp. (1999) 
No. 21 Status of the Western Blue Flag (Iris missouriensis) in Alberta, by Joyce Gould. 22 pp. (1999)

No. 22 Status of the Long-toed Salamander (Ambystoma macrodactylum) in Alberta, by Karen L. Graham and G. Lawrence Powell. 19 pp. (1999)

No. 23 Status of the Black-throated Green Warbler (Dendroica virens) in Alberta, by Michael R. Norton. 24 pp. (1999)

No. 24 Status of the Loggerhead Shrike (Lanius ludovicianus) in Alberta, by David R. C. Prescott and Ronald R. Bjorge. 28 pp. (1999)

No. 25 Status of the Plains Spadefoot (Spea bombifrons) in Alberta, by Richard D. Lauzon. 17 pp. (1999)

No. 26 Status of the Trumpeter Swan (Cygnus buccinator) in Alberta, by M. Lynne James. 21 pp. (2000)

No. 27 Status of the Pygmy Whitefish (Prosopium coulteri) in Alberta, by William C. Mackay. 16 pp. (2000)

No. 28 Status of the Short-eared Owl (Asio flammeus) in Alberta, by Kort M. Clayton. 15 pp. (2000)

No. 29 Status of the Willow Flycatcher (Empidonax traillii) in Alberta, by Bryan Kulba and W. Bruce McGillivray. 15 pp. (2001).

No. 30 Status of the Woodland Caribou (Rangifer tarandus caribou) in Alberta, by Elston Dzus. 47 pp. (2001)

No. 31 Status of the Western Spiderwort (Tradescantia occidentalis) in Alberta, by Bonnie Smith. 12 pp. (2001)

No. 32 Status of the Bay-breasted Warbler (Dendroica castanea) in Alberta, by Michael Norton. 21 pp. (2001)

No. 33 Status of the Cape May Warbler (Dendroica tigrina) in Alberta, by Michael Norton. 20 pp. (2001)

No. 34 Status of the Whooping Crane (Grus americana) in Alberta, by Jennifer L. White. 21 pp. (2001)

No. 35 Status of Soapweed (Yucca glauca) in Alberta, by Donna Hurlburt. 18 pp. (2001)

No. 36 Status of the Harlequin Duck (Histrionicus histrionicus) in Alberta, by Beth MacCallum. 38 pp. (2001)

No. 37 Status of the Grizzly Bear (Ursus arctos) in Alberta, by John L. Kansas. 43 pp. (2002)

No. 38 Status of the Wood Bison (Bison bison athabascae) in Alberta, by Jonathan A. Mitchell and C. Cormack Gates. 32 pp. (2002)

No. 39 Status of the Bull Trout (Salvelinus confluentus) in Alberta, by John R. Post and Fiona D. Johnston. 40 pp. (2002)

No. 40 Status of the Banff Springs Snail (Physella johnsoni) in Alberta, by Dwayne A.W. Lepitzki. 29 pp. (2002)

No. 41 Status of the Shortjaw Cisco (Coregonus zenithicus) in Alberta, by Mark Steinhilber. 23 pp. (2002)

No. 42 Status of the Prairie Falcon (Falco mexicanus) in Alberta, by Dale Paton. 28 pp. (2002)

No. 43 Status of the American Badger (Taxidea taxus) in Alberta, by Dave Scobie. 17 pp. (2002)

No. 44 Status of the Yucca Moth (Tegeticula yuccasella) in Alberta. Alberta Sustainable Resource Development. 21 pp. (2002) 
No. 45 Status of the White-winged Scoter (Melanitta fusca deglandi) in Alberta. Alberta Sustainable Resource Development. 15 pp. (2002)

No. 46 Status of the Lake Sturgeon (Acipenser fulvescens) in Alberta. Alberta Sustainable Resource Development. $30 \mathrm{pp} .(2002)$

No.47 Status of the Western Silvery Minnow (Hybognathus argyritis) in Alberta. Alberta Sustainable Resource Development. 24 pp. (2003)

No. 48 Status of the Small-flowered Sand Verbena (Tripterocalyx micranthus) in Alberta. Alberta Sustainable Resource Development. 24 pp. (2003)

No. 49 Status of the Brown Creeper (Certhia americana) in Alberta. Alberta Sustainable Resource Development. 30 pp. (2003)

No. 50 Status of the Mountain Plover (Charadrius montanus) in Alberta. Alberta Sustainable Resource Development. 25 pp. (2003)

No. 51 Status of the St. Mary Shorthead Sculpin (provisionally Cottus bairdi punctulatus) in Alberta. Alberta Sustainable Resource Development. 24 pp. (2003)

No. 52 Status of the Stonecat (Noturus flavus) in Alberta. Alberta Sustainable Resource Development. 22 pp. (2003)

No. 53 Status of the Sage Thrasher (Oreoscoptes montanus) in Alberta. Alberta Sustainable Resource Development. 23 pp. (2004)

No. 54 Status of the Tiny Cryptanthe (Cryptantha minima) in Alberta. Alberta Sustainable Resource Development. 39 pp. (2004) 



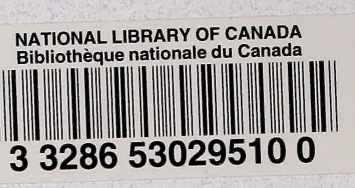

